\title{
Transplantation of Human Neural Stem Cells Exerts Neuroprotection in a Rat Model of Parkinson's Disease
}

\author{
Takao Yasuhara, ${ }^{1}$ Noriyuki Matsukawa, ${ }^{1}$ Koichi Hara, ${ }^{1}$ Guolong $\mathrm{Yu},{ }^{1}$ Lin $\mathrm{Xu},{ }^{1}$ Mina Maki, ${ }^{1}$ Seung U. Kim,${ }^{2,3}$ and \\ Cesario V. Borlongan ${ }^{1,4}$ \\ ${ }^{1}$ Department of Neurology, Medical College of Georgia, Augusta, Georgia 30912, 2isease Research Center, Ajou University School of Medicine, Suwon 443- \\ 721, Korea, ${ }^{3}$ Division of Neurology, University of British Columbia Hospital, Vancouver, British Columbia, Canada V5Z 1M9, and ${ }^{4}$ Research and Affiliations \\ Service Line, Augusta Veterans Affairs Medical Center, Augusta, Georgia 30904
}

Neural stem cells (NSCs) possess high potencies of self-renewal and neuronal differentiation. We explored here whether transplantation of human NSCs cloned by v- $m y c$ gene transfer, HB1.F3 cells, is a feasible therapeutic option for Parkinson's disease. In vivo, green fluorescent protein-labeled HB1.F3 cells (200,000 viable cells in $3 \mu \mathrm{l}$ of PBS) when stereotaxically transplanted (same-day lesiontransplant paradigm) into the 6-hydroxydopamine-lesioned striatum of rats significantly ameliorated parkinsonian behavioral symptoms compared with controls (vehicle, single bolus, or continuous minipump infusion of trophic factor, or killed cell grafts). Such graft-derived functional effects were accompanied by preservation of tyrosine hydroxylase $(\mathrm{TH})$ immunoreactivity along the nigrostriatal pathway. Grafted HB1.F3 cells survived in the lesioned brain with some labeled with neuronal marker mitogen-activated protein 2 and decorated with synaptophysin-positive terminals. Furthermore, endogenous neurogenesis was activated in the subventricular zone of transplanted rats. To further explore the neuroprotective mechanisms underlying HB1.F3 cell transplantation, we performed cell culture studies and found that a modest number of HB1.F3 cells were TH and dopamine and cAMP-regulated phosphoprotein 32 positive, although most cells were nestin positive, suggesting a mixed population of mature and immature cells. Administration of the HB1.F3 supernatant to human derived dopaminergic SH-SY5Y cells and fetal rat ventral mesencephalic dopaminergic neurons protected against 6-hydroxydopamine neurotoxicity by suppressing apoptosis through Bcl-2 upregulation, which was blocked by anti-stem cell factor antibody alone, the phosphatidylinositol 3-kinase/Akt inhibitor LY294002 [2-(4-morpholinyl)-8-phenyl-1(4H)-benzopyran-4-one] alone, or a combination of both. These results suggest that HB1.F3 cell transplantation exerts neuroprotective effects against dopaminergic depletion in vitro and in vivo because of trophic factor secretion and neuronal differentiation.

Key words: apoptosis; neurogenesis; neuroprotection; neurodegeneration; stem cell factor; trophic

\section{Introduction}

Parkinson's disease $(\mathrm{PD})$ is characterized by an extensive loss of dopamine neurons in the substantia nigra pars compacta $(\mathrm{SNc})$ and their terminals in the striatum (Hornykiewicz, 1973; Calne, 1984 ) and affects $>500,000$ people in the United States (Alexi et al., 2000). The current standard of treatment for PD is oral L-3,4dihydroxyphenylalanine, which provides symptomatic relief but does not retard the disease progression (Lang and Lozano, 1998a,b).

Neural transplantation of fetal ventral mesencephalic (VM) dopaminergic neurons has been introduced in the clinic as an alternative treatment for PD (Lindvall et al., 1988, 1992; Madrazo et al., 1988; Freeman et al., 1995; Kordower et al., 1995; Borlongan et al., 1999; Borlongan, 2000). However, recent clinical trials

Received April 25, 2006; revised 0ct. 23, 2006; accepted 0ct. 25, 2006.

C.V.B. is supported by a Veterans Affairs Merit Review and Medical College of Georgia Department of Neurology Cell Transplantation Funds. We thank Dr. Didier Trono for kind provision of the lentiviral vector plasmids and Dr. Katsuya Miyake for excellent photomicrographs.

Correspondence should be addressed to Dr. Cesario V. Borlongan, Department of Neurology, Medical College of Georgia, 1120, 15th Street, BI-3080, Augusta, GA 30912-3200. E-mail:cborlongan@mail.mcg.edu.

DOI:10.1523/JNEUROSCI.3719-06.2006

Copyright $\odot 2006$ Society for Neuroscience $\quad$ 0270-6474/06/2612497-15\$15.00/0 have generated mixed results in that transplantation of fetal VM cells was shown to induce dyskinesia in some patients (Freed et al., 2001; Olanow et al., 2003), whereas excellent graft dopaminergic reinnervation of the parkinsonian affected striatum accompanied positive clinical improvements in transplanted patients who did not develop dyskinesia (Mendez et al., 2005). Optimizing the graft material, among several other technical factors, is likely to improve the outcome and avoid adverse effects of fetal VM grafts.

Logistical issues, in particular the difficulty in obtaining ample supply of fetal VM cells coupled with their poor graft survival, limit the clinical applicability of fetal dopamine cell transplants (Borlongan and Sanberg, 2002; Freed, 2002). Finding an unlimited source of dopamine cells would be a welcome advance in cell transplant therapy. The infinite self-renewal capacity and neuronal differentiation potential of stem/progenitor cells make them an appealing donor graft source for cell therapy in PD (Snyder and Olanow, 2005; Sonntag et al., 2005). Candidate stem/progenitor cells for transplantation therapy in PD have been evaluated using several criteria, including their in vitro and in vivo phenotypic expression of the dopamine synthetic enzyme tyrosine hydroxylase (TH), as well as markers for dopamine transporter, 
their capacity to synthesize, release, take up, and catabolize dopamine, and also their ability to project axons to target nuclei such as the putamen (Arenas, 2002; Bjorklund et al., 2002; Lindvall and Bjorklund, 2004; Langston, 2005; Takagi et al., 2005). Although there is absent or minimal detection of fully mature neuronal differentiation of stem/progenitor cells into dopaminergic neurons, attenuation of parkinsonian symptoms have been observed, possibly as a result of the secretion of neurotrophic factors by the cells(Jung et al., 2004; Goldman, 2005; Rafuse et al., 2005).

In this study, we evaluated human HB1.F3 neural stem cells (NSCs) as graft source for PD. Initially, we transplanted HB1.F3 cells into the striatum of 6-OHDA-lesioned rats and assessed whether the cells produced behavioral benefits and protected against dopaminergic depletion. To reveal mechanisms underlying the therapeutic outcome, we subsequently characterized the neuronal phenotype of grafted HB1.F3 cells and their potential to activate the endogenous neurogenesis, especially in the subventricular zone (SVZ) adjacent to the transplant site. In addition, cultured human dopaminergic SH-SY5Y cells and fetal rat ventral mesencephalic dopaminergic cells were used to examine secretion of neurotrophic factors by HB1.F3 cell grafts.

\section{Materials and Methods}

In vivo study

Production of green fluorescent protein-HB1.F3 cells. HB1.F3 cells, a human fetal-derived neural stem cell line, as described previously in detail, were kindly provided by Dr. Seung U. Kim (University of British Columbia, Vancouver, British Columbia, Canada) (Flax et al., 1998; Cho et al., 2002; Kim, 2004). Briefly, primary dissociated cell cultures from the periventricular region of human telencephalic tissues of 14 weeks gestation were prepared and grown for $10 \mathrm{~d}$. Thereafter, cells were infected with an amphotropic, replication-incompetent retroviral vectorcontaining v- $m y c$, and, subsequently, HB1.F3 cells were cloned. For easy detection of possible migration of transplanted cells, HB1.F3 cells were green fluorescent protein (GFP) labeled by lentivirus (Klages et al., 2000; Lundberg et al., 2002), which were kindly provided by Prof. Didier Trono (University of Geneva, Geneva, Switzerland). Briefly, pWPT-GFP as a transfer vector, $\mathrm{pMDL} g / \mathrm{pRRE}$ and $\mathrm{pRSV}-\mathrm{Rev}$ as packaging plasmid, and pMD2.G as an envelope plasmid were transfected to HEK293T cells (Invitrogen, Carlsbad, CA). The supernatant with viruses was collected twice for $2 \mathrm{~d}$, and $1 \times 10^{7}$ transducing units/ml of viruses were transfected to HB1.F3 cells. Morphological changes were monitored by phasecontrast microscopy (Nikon, Tokyo, Japan). Furthermore, to demonstrate the neuronal phenotypes, the degree of maturation, and the differences between GFP-HB1.F3 cells and non-GFP-HB1.F3 cells, immunocytochemical investigations were performed as described below with antibodies directed against human nuclei (mouse monoclonal IgG, 1:500; Chemicon, Temecula, CA), nestin (mouse monoclonal IgG, 1:500; Chemicon), microtubule-associated protein 2 (MAP2) (rabbit polyclonal IgG, 1:500; Chemicon), $\beta$-tubulin III (mouse monoclonal IgG, 1:500; Chemicon), HuC (rabbit polyclonal IgG, 1:500; Chemicon), HuD (rabbit polyclonal IgG, 1:500; Chemicon), neuronal-specific nuclear protein (NeuN) (mouse monoclonal IgG, 1:200; Chemicon), TH (rabbit polyclonal IgG, 1:500; Chemicon), dopamine and cAMP-regulated phosphoprotein 32 (DARPP32) (rabbit polyclonal IgG, 1:500; Abcam, Cambridge, MA), and choline acetyltransferase (ChAT) (goat polyclonal IgG, 1:500; Chemicon) with secondary antibodies [goat anti-mouse/ anti-rabbit/anti-goat IgG Alexa Fluor 594 and bisBenzimideH 33342 trihydrochloride (Hoechst33342; 1:1000; Sigma, St. Louis, MO)]. For estimation of neuronal marker expression, randomly selected visual fields were photographically captured (Axiophot2; Zeiss, Oberkochen, Germany), and cells were quantified by counting per high-power field view also selected at random ( $n=6$ in each group, $\left.28,800 \mu \mathrm{m}^{2}\right)$. Control studies involved exclusion of primary antibody substituted with $10 \%$ normal horse serum in PBS. No immunoreactivity was observed in these controls.
Subjects and surgical procedures. We used 72 Sprague Dawley rats (200-250 g at the beginning of the experiment; Harlan Sprague Dawley, Indianapolis, IN) according to the approved guidelines of the institutional animal care and use committee of Augusta Veterans Affairs Medical Center. They were housed singly in a temperature and humidity controlled room that was maintained on $12 \mathrm{~h}$ light/dark cycles, with access to food and water ad libitum. All surgical procedures were conducted under aseptic conditions. Rats were anesthetized using Equithesin (300 mg/kg, i.p.) and received 6-OHDA injection ( $8 \mu \mathrm{g} / 3 \mu \mathrm{l}$ in saline containing $0.2 \mathrm{mg} / \mathrm{ml}$ ascorbic acid; Sigma) in the right medial forebrain bundle [target coordinates: anteroposterior (AP), -4.0; mediolateral (ML), 0.8; dorsoventral (DV), $8.0 \mathrm{~mm}$ from bregma] using a Hamilton syringe (26 gauge needle). Immediately after the lesion surgery, 32 rats received ipsilateral intrastriatal transplantation of GFP-HB1.F3 cells (200,000/3 $\mu \mathrm{l}$ in PBS) (target coordinates: AP, 0.5; ML, 3.0; DV, $5.0 \mathrm{~mm}$ from bregma) was performed using a stereotaxic instrument (David Kopf Instruments, Tujunga, CA). These transplanted rats were killed at selected time points (day 3 , week 1 , week 2 , or week 4 after transplantation) to reveal graft survival over time. A total of 40 rats ( $n=8$ per group) served as controls as follows: vehicle ( $3 \mu$ lof PBS), dead HB1.F3 cells by freeze-thaw cycle regimen (Modo et al., 2003) $(200,000 / 3 \mu \mathrm{l}$ in PBS), culture medium (CM) derived from HB1.F3 cells $(3 \mu \mathrm{l})$, human recombinant stem cell factor (SCF) ( 500 pg/3 $\mu$ l; R \& D Systems, Minneapolis, $\mathrm{MN}$ ), and continuous SCF infusion (500 pg/d) using osmotic minipumps (model 2004; Alzet, Cupertino, CA). Each control solution was stereotaxically injected into the original striatal transplant coordinates, while the osmotic minipump was intrastriatally placed targeting also the same transplant coordinates. Animals were placed on a temperature-controlled blanket until they recovered from the anesthesia. All rats received daily immunosuppression $(10 \mathrm{mg} / \mathrm{kg}$ cyclosporin $\mathrm{A}$, i.p.), which was started on the day of transplantation and was maintained throughout the survival period.

Behavioral testing. Spontaneous locomotor activity test, cylinder test, and apomorphine-induced rotational test were performed before transplantation and at 2 and 4 weeks after transplantation (supplemental Fig. $1 A$, available at www.jneurosci.org as supplemental material). For spontaneous locomotor test, each rat was placed in the Accuscan (Columbus, $\mathrm{OH})$ monitor box, which was made of Plexiglas $(42 \times 42 \times 30 \mathrm{~cm})$ and equipped with infrared beams programmed to collect, over a $12 \mathrm{~h}$ period, hourly data of eight behavioral parameters (horizontal activity, total distance traveled, movement number, movement time, resting time, vertical activity, vertical movement number, and vertical movement time). Mean hourly data for each behavioral parameter were used for analysis.

Forelimb akinesia was analyzed with the modified cylinder test (Kirik et al., 2000; Schallert et al., 2000; Iancu et al., 2005). Briefly, rats were placed individually in a glass cylinder $(21 \times 34 \mathrm{~cm})$ equipped with a video camera. After 10 rears, weight-bearing contacts by each forelimb on the cylinder wall were counted. Data were analyzed as percentages of left forelimb contacts over total contacts.

Rats were also challenged with apomorphine $(0.3 \mathrm{mg} / \mathrm{kg}$, s.c.; Sigma), and rotational behaviors were assessed for $60 \mathrm{~min}$ with a video camera. Full $360^{\circ}$ turns contralateral to the lesion were counted.

Bromodeoxyuridine labeling. To reveal whether HB1.F3 cells activated endogenous neurogenesis in the SVZ, bromodeoxyuridine (BrdU) proliferative cells were evaluated (supplemental Fig. $1 \mathrm{~A}$, available at www. jneurosci.org as supplemental material). For labeling of proliferative cells (Chen et al., 2004), all rats received daily BrdU injection $(50 \mathrm{mg} / \mathrm{kg}$, i.p.; Sigma) for 2 weeks before they were killed.

Fixation and sectioning. At day 3, week 1, week 2, or week 4 after transplantation surgery, under deep anesthesia with Equithesin $(500 \mathrm{mg} /$ $\mathrm{kg}$, i.p.), randomly selected rats were perfused through the ascending aorta with $200 \mathrm{ml}$ of cold PBS, followed by $150 \mathrm{ml}$ of $4 \%$ paraformaldehyde (PFA) in PBS. Brains were removed and postfixed in the same fixative for $24 \mathrm{~h}$, followed by $30 \%$ sucrose in phosphate buffer for 1 week. Six series of coronal sections were cut at a thickness of $20 \mu \mathrm{m}$ in a freezing microtome (Leica, Nussloch, Germany) and stored at $-20^{\circ} \mathrm{C}$.

Immunohistochemistry. To demonstrate graft survival, neuronal phenotype expression, and synapse formation, immunohistochemical investigations were performed. Free-floating sections were incubated over- 
night at $4^{\circ} \mathrm{C}$ with an anti-MAP2 antibody (mouse monoclonal or rabbit polyclonal IgG, 1:1000; Chemicon), anti-TH antibody (mouse monoclonal or rabbit polyclonal IgG, 1:1000; Chemicon), an anti-human nuclei antibody (mouse monoclonal IgG, 1:300; Chemicon), an antisynaptophysin antibody (mouse monoclonal IgM, 1:500; Abcam), an anti-c-kit antibody (rabbit polyclonal IgG, 1:200; Abcam), an anti-TrkB antibody (rabbit polyclonal IgG, 1:200; Chemicon), and an antiDoublecortin (Dcx) antibody (guinea pig polyclonal IgG, 1:1000; Abcam) with $10 \%$ normal horse serum (Vector Laboratories, Burlingame, CA) and $0.2 \%$ Triton X-100 (Fischer Scientific, Pittsburgh, PA) except for staining with anti-TrkB and c-kit antibodies. A slightly modified BrdU staining (Greisen et al., 2005) was used. Briefly, sections were incubated in $\mathrm{HCl}\left(1 \mathrm{~N}, 37^{\circ} \mathrm{C}\right)$ for $30 \mathrm{~min}$. After rinses with PBS three times, sections were incubated for $36 \mathrm{~h}$ at $4^{\circ} \mathrm{C}$ with an anti-BrdU antibody (rat monoclonal IgG, 1:200; Serotec, Raleigh, NC), 10\% of normal horse serum, and $0.3 \%$ of Triton X-100. After several rinses in PBS, sections were incubated for $1 \mathrm{~h}$ in goat anti-mouse IgG Alexa Fluor 350/488/594 conjugate (1:500/1:500/1:1000; Invitrogen), goat anti-rabbit IgG Alexa Fluor 488/594 conjugate (1:500/1:1000), goat anti-rat IgG Alexa Fluor 488 (1:500), or donkey anti-guinea pig IgG Alexa Fluor 594 (1:1000) with Hoechst33342 (1:1000; Sigma). The sections were then washed three times in PBS and mounted on Superfrost Plus glass slides (Erie Scientific, Portsmouth, NH) and embedded with mounting medium (Biomeda, Foster City, CA). Control studies included exclusion of primary antibody substituted with $10 \%$ normal horse serum in PBS. No immunoreactivity was observed in these controls.

Morphological analysis. The degree of dopaminergic preservation, graft survival, and endogenous neurogenesis were immunohistochemically analyzed. For estimation of preservation of TH-positive fibers in the striatum and neurons in the SNc, surviving rate of transplanted cells, and BrdU/Dcx double-positive cells in the SVZ, randomly selected visual fields were photographically captured (Axiophot2; Zeiss), and cells were quantified by counting per high-power field view also selected at random $\left(28,800 \mu \mathrm{m}^{2}\right)$ and corrected by the Abercrombie formula. Two captured fields in each coronal level, using three levels, were used to analyze the density of TH-positive fibers in the striatum (AP, 1.5, 0.5, and $-0.5 \mathrm{~mm}$ to bregma) and $\mathrm{TH}$-positive neurons in the $\mathrm{SNc}(\mathrm{AP},-4.8,-5.3$, and $-5.8 \mathrm{~mm}$ ) (Paxinos and Watson, 1998). For analyses of the density of TH-positive fibers in the striatum, two areas of the right striatum (lesioned with or without transplantation) and the two corresponding areas in the contralateral side were analyzed using Scion Image software (Scion, Frederick, MD). Binary images were created using a distinct threshold, and then the positive areas were calculated and summed up. The ratio of the value in the lesioned striatum to the intact side was used for statistical analyses. For estimation of TH-positive neurons in the $\mathrm{SNc}$, $\mathrm{TH}$-positive cell bodies across three coronal levels of the SNc, using two sections per level, were counted and summed up in each level, and the percentages to the intact side were calculated. For evaluation of graft survival, GFP-labeled cells stained with human nuclei antibody and Hoechst 33342 were counted every fifth 20 - $\mu$ m-thick coronal tissue section through the transplanted striatum. For assessment of BrdU/Dcx double-positive cells in the SVZ, three sections at bregma level were captured, and the number of double-positive cells was counted in four defined areas $(200 \times 60 \mu \mathrm{m})$ of the lateral ventricle wall (Baldauf and Reymann, 2005). Additionally, confocal analysis was performed using Zeiss LSM 510 confocal laser scanning microscope.

\section{In vitro study}

Effects of HB1.F3-derived culture media on 6-OHDA neurotoxicity. To create an in vitro PD model, human dopaminergic SH-SY5Y neurons (American Type Culture Collection, Manassas, VA) were exposed to 6-OHDA (supplemental Fig. $1 B$, available at www.jneurosci.org as supplemental material) (Spina et al., 1992; Maruyama et al., 2001, 2002). SH-SY5Y cells were cultured at a density of $1 \times 10^{4}$ cells per well on LAB-TEK chamber slide (Nalge Nunc, Rochester, NY) for immunocytochemical investigation or on a 96-well plate (Evergreen Scientific, Los Angeles, CA) for MTT assay (Promega, Madison, WI) in DMEM (Invitrogen) with high glucose supplemented with $10 \%$ fetal bovine serum (FBS) (Invitrogen), $100 \mathrm{I} . \mathrm{U} / \mathrm{ml}$ penicillin, and $100 \mu \mathrm{g} / \mathrm{ml}$ streptomycin
(Mediatech, Herndon, VA). At $2 \mathrm{~d}$ after culture, cells were exposed to 1, 10 , and $40 \mu \mathrm{M} 6$-OHDA (Sigma) or PBS for 12 or $24 \mathrm{~h}$ at $37^{\circ} \mathrm{C}$. After this exposure, the medium was removed and the cultures were analyzed. Each treatment condition was replicated three times using three different cell cultures. After confirmation of appropriate 6-OHDA neurotoxic doses, we examined the neuroprotective effects of HB1.F3 cells in 6-OHDAexposed SH-SY5Y cells.

Neurotrophic effects of HB1.F3 cells were explored using the CM (supplemental Fig. 1C, available at www.jneurosci.org as supplemental material). To collect the CM, HB1.F3 cells were cultured in $4 \mathrm{ml}$ of medium at $1 \times 10^{6}$ cells $/ 25 \mathrm{~cm}^{2}$ flask (Becton Dickinson, Hunt Valley, $\mathrm{MD})$. At $2 \mathrm{~d}$ after culture, CM was exchanged to $2 \mathrm{ml}$ of plain DMEM, and cells were incubated for $24 \mathrm{~h}$, filtered with $0.22 \mu \mathrm{m}$ syringe filter (Fischer Scientific), and preserved at $-80^{\circ} \mathrm{C}$. The number of HB1.F3 cells was counted for accurate secretory function per $10^{6}$ cells. Thereafter, SH-SY5Y cells were cultured as described above. At $2 \mathrm{~d}$ after culture, medium was exchanged to DMEM with 5\% FBS as a control or mixture of DMEM with $10 \%$ FBS and preserved CM (1:1). Ten minutes later, 6-OHDA was added to the final concentration of $40 \mu \mathrm{M}$ as per our previous studies and those of others (Maruyama et al., 2001, 2002; Yasuhara et al., 2004, 2005). At $24 \mathrm{~h}$ after 6-OHDA treatment, the cultures were examined using MTT assay (Promega) or immunocytochemically (see below). Each treatment condition was replicated three times using three different cell cultures.

Cell-cell interactive effects of HB1.F3 cells were also explored using coculture of fixed cells (supplemental Fig. $1 D$, available at www. jneurosci.org as supplemental material). Each $2 \times 10^{3} \mathrm{HB}$.F3 cells were plated on LAB-TEK chamber slides. At $24 \mathrm{~h}$ after culture, cells were fixed with $1 \%$ PFA for $1 \mathrm{~h}$ on ice and washed in PBS five times. This procedure preserved membrane integrity but deleted cell secretory function (Kuroiwa et al., 1999; Olsnes et al., 2002). SH-SY5Y cells were cultured at a density of $1 \times 10^{4}$ cells per well on the chamber slide with fixed HB1.F3 cells. At $48 \mathrm{~h}$ after SH-SY5Y cell culture, $40 \mu \mathrm{M}$ 6-OHDA or PBS were added to the cells. Finally, cells were fixed and analyzed immunocytochemically after another $24 \mathrm{~h}$.

Cell viability was evaluated with MTT assay following the protocol of the manufacturer (Promega). Briefly, MTT assay was performed by adding $100 \mu \mathrm{l}$ of MTT assay solution to $100 \mu \mathrm{l}$ of medium containing cells in a 96-well plate after incubation of cells with 6-OHDA. The intensities of chemiluminescence of MTT activity were measured and calculated by Image station 2000R system (Eastman Kodak, Rochester, NY). In parallel, immunocytochemical evaluation of SH-SY5Y cells was performed as described previously (Yasuhara et al., 2005). Briefly, after fixation by $4 \%$ PFA for 20 min and washing with PBS three times, cells were incubated overnight at $4^{\circ} \mathrm{C}$ with TH antibody (rabbit polyclonal IgG, 1:500; Chemicon) with $10 \%$ normal horse serum (Vector Laboratories). After rinses in PBS three times, cells were incubated at room temperature for $30 \mathrm{~min}$ in goat anti-rabbit IgG Alexa Fluor 488 conjugate (1:1000; Invitrogen) and Hoechst33342 (1:2000; Sigma). The cells were then washed three times in PBS and embedded with mounting medium. For estimation of cell viability, randomly selected visual fields were photographically captured (Axiophot2; Zeiss), and cells were quantified by counting per high-power field view also selected at random $\left(n=6\right.$ in each group, $\left.28,800 \mu \mathrm{m}^{2}\right)$. In addition, we used the following antibodies to reveal neuronal phenotypes of SH-SY5Y cells: primary antibodies included human nuclei (mouse monoclonal IgG, 1:500; Chemicon), nestin (mouse monoclonal IgG, 1:500; Chemicon), MAP2 (rabbit polyclonal IgG, 1:500; Chemicon), and $\beta$-tubulin III (mouse monoclonal IgG, 1:500; Chemicon), whereas secondary antibodies consisted of goat anti-mouse/anti-rabbit IgG Alexa Fluor 488 conjugate (1:1000; Invitrogen). Control studies involved exclusion of primary antibody substituted with $10 \%$ normal horse serum in PBS. No immunoreactivity was observed in these controls.

Secretory function of HB1.F3 cells. Trophic factors such as SCF, brain derived-neurotrophic factor (BDNF), glial cell line-derived neurotrophic factor (GDNF), and vascular endothelial growth factor (VEGF) have been detected as critical secretory factors in immature NSCs (SieberBlum, 1998; Lu et al., 2003; Llado et al., 2004). Thus, we measured these molecules as possible neurotrophic factors secreted by HB1.F3 cells. In addition to the CM of HB1.F3 cells collected as described above, 
SH-SY5Y cells and human-derived multipotent progenitor cells (hMPCs) (a kind gift from Athersys, Cleveland, $\mathrm{OH}$ ) were also cultured, which served as the control cell line for evaluation of trophic factor secretion. The levels of BDNF, GDNF, VEGF, and SCF released from 1 million HB1.F3 or SH-SY5Y cells were determined using ELISA kits according to the protocols of the manufacturer (BDNF and GDNF from Promega; human VEGF and human SCF from R \& D Systems). The CM of the cells was analyzed by interpolation from the standard curves assayed on individual plates. These ELISA systems can detect a minimum of 7.8, 15.6, 31.2, and 31.2pg/ml BDNF, GDNF, VEGF, and SCF, respectively. Both GFP-HB1.F3 cells and non-GFP-HB1.F3 had the same potencies to secrete specific growth factors in vitro.

Validation of dominant trophic factors secreted by HB1.F3 cells. ELISA revealed that HB1.F3 cells secreted BDNF and SCF. Next, to confirm which highly potent neurotrophic factors exerted the neuroprotective effects, the combination of the CM and anti-SCF antibody (rabbit polyclonal IgG, $10 \mathrm{ng} / \mathrm{ml}$; Abcam) or anti-BDNF antibody (rabbit polyclonal IgG, $10 \mathrm{ng} / \mathrm{ml}$; Abcam) was used. In addition, SCF-removed CM by immunoprecipitation (Kirkegaard \& Perry Laboratories, Gaithersburg, $\mathrm{MD}$ ) was also performed to eliminate possible effects of SCF-antibody complex (supplemental Fig. $1 E$, available at www.jneurosci.org as supplemental material).

Because the antibody neutralizing/removal data indicated the apparent dominance of SCF over BDNF, we proceeded to explore the direct neuroprotective effects of SCF against 6-OHDA neurotoxicity in $\mathrm{SH}$ SY5Y cells. Recombinant human SCF (R \& D Systems) was tested in a similar manner. Two doses of SCF ( 5 and $500 \mathrm{ng} / \mathrm{ml}$ ) were chosen by the secreted amount of SCF in the CM of HB1.F3 and the $\mathrm{ED}_{50}(2.5 \mathrm{ng} / \mathrm{ml}$; information from R \& D Systems). SCF was added to cultured SH-SY5Y cells using the same paradigm as above, consisting of CM treatment with or without anti-SCF antibody (supplemental Fig. $1 E$, available at www. jneurosci.org as supplemental material).

Mechanisms underlying SCF neuroprotection. To clarify whether neuroprotective effects of the $\mathrm{CM}$ with SCF involved anti-apoptotic effects, a modified method for terminal deoxynucleotidyl transferase-mediated biotinylated UTP nick end labeling, (TUNEL) (Roche, Mannheim, Germany) was performed to evaluate apoptotic cell death, as described in our previous report (Yasuhara et al., 2004). At $12 \mathrm{~h}$ after 6-OHDA treatment, cultured cells with or without CM treatment were fixed with $4 \%$ PFA for $20 \mathrm{~min}$ and then washed with PBS (supplemental Fig. $1 F$, available at www.jneurosci.org as supplemental material). Nuclear staining with Hoechst33342 (1:2000) was performed at the same time, and the staining pattern of apoptotic cells was confirmed microscopically. The number of TUNEL-positive apoptotic cells was counted per high-power field view selected at random $\left(n=6\right.$ in each group, 288,000 $\left.\mu \mathrm{m}^{2}\right)$. Each treatment condition was replicated three times using three different cell cultures.

After confirming the involvement of anti-apoptotic effects of HB1.F3 cell-derived CM, we measured expression of c-kit, the SCF receptor, and TrkB, the BDNF receptor, on non-6-OHDA-exposed SH-SY5Y cells using antibodies against c-kit (rabbit polyclonal IgG, 1:200; Abcam) and TrkB (rabbit polyclonal IgG, 1:200; Chemicon). BDNF neuroprotection against 6-OHDA toxicity in SH-SY5Y cells has been reported previously to involve TrkB (Spina et al., 1992), but, to date, the role of c-kit expression, via which SCF might exert neuroprotection (Ashman, 1999), remains to be fully determined. We investigated here c-kit expression after exposure of SH-SY5Y cells to 1, 10, or $40 \mu \mathrm{M}$ 6-OHDA (supplemental Fig. $1 G$, available at www.jneurosci.org as supplemental material). We also examined the molecular signaling pathway involved in SCF neuroprotection by treatment with LY294002 [2-(4-morpholinyl)-8-phenyl1(4H)-benzopyran-4-one], a phosphatidylinositol 3-kinase (PI3k)/Akt inhibitor (600 ng/ml; Calbiochem, La Jolla, CA), using the same paradigm as the neutralizing antibody experiment (supplemental Fig. $1 E$, available at www.jneurosci.org as supplemental material). Although SCF-c-kit binding activates multiple signaling components, PI3k/Akt is the widely characterized pathway (Linnekin, 1999); thus, we focused on this signaling mechanism.

Bcl-2 expression, which directly exerts anti-apoptotic effects through Akt/PI3k pathways (Farlie et al., 1995), appears primarily affected by
SCF-c-kit binding (McGill et al., 2002). Thus, Bcl-2 protein level was quantitatively measured to explore whether anti-apoptotic effects of SCF in 6-OHDA-exposed dopaminergic neurons was mediated by Bcl-2 upregulation (supplemental Fig. $1 \mathrm{H}$, available at www.jneurosci.org as supplemental material). After each treatment of CM or SCF with or without anti-SCF antibody and LY294002 to 6-OHDA-exposed SH-SY5Y cells, attached cells cultured on $6 \mathrm{~cm}$ dishes (Falcon, Franklin Lakes, NJ) were washed in PBS and collected in radioimmunoprecipitation assay (RIPA) buffer (Sigma) with protease inhibitor cocktail (Complete mini; Roche) at 3, 6, 12, and $24 \mathrm{~h}$ after 6-OHDA treatment. Cell lysates were prepared for Bcl-2 ELISA following the protocol of the manufacturer (Calbiochem). Briefly, antigen extraction agent was added to the cell lysates in RIPA buffer and incubated on ice for $30 \mathrm{~min}$. Lysates were centrifuged, and the supernatant was preserved at $-80^{\circ} \mathrm{C}$. To measure $\mathrm{Bcl}-2$ protein from the same number of cells, the total amount of protein in each lysate was assayed (Biophotometer; Eppendorf Scientific, Westbury, NY). The amount of $\mathrm{Bcl}-2$ protein was evaluated per equal quantity of total protein because the number of attached cells during 6-OHDA exposure decreased over time.

After the series of in vitro studies using SH-SY5Y cells, neuroprotective effects of CM and SCF were also confirmed using rat-derived ventral mesencephalic dopaminergic neurons (BrainBits, Springfield, IL) (supplemental Fig. $1 I$, available at www.jneurosci.org as supplemental material). In accordance with the instructions of the manufacturer, cells were cultured with the prepared medium (Neurobasal/B27/0.5 mM glutamine) on lysine-coated 96-well dishes for MTT assay ( $n=4$ in each condition) or chamber slides for immunocytochemical assay $(n=3$ in each condition). The SH-SY5Y protocol was followed except for the initial plating duration and the dose of 6-OHDA $(20 \mu \mathrm{M})$, determined as the "effective toxic dose" for this cell type in our preliminary studies (data not shown). In addition, c-kit expression was also explored in these dopaminergic neurons.

Statistical analysis. Secreted factors from cultured cells, cell viability, TUNEL-positive cells, and Bcl-2 expression with various treatments in vitro and immunohistochemical/behavioral data in vivo were evaluated using repeated-measures ANOVA or one-way ANOVA, followed by post hoc Scheffé's test. Statistical significance was preset at $p<0.05$.

\section{Results}

\section{In vivo study}

Establishment of GFP-HB1.F3 cells

Most of the HB1.F3 cells were well stained with anti-nestin, anti$\beta$-tubulin III, anti-HuNu, and anti-HuD, and some stained with anti-MAP2 and rarely stained with anti-NeuN, but none were positive for anti-HuC antibody, confirming that this cell line was human derived, with most cells expressing early neuronal progenitor phenotypic markers (Fig. 1). Some cells strongly expressed DARPP32, and a few expressed TH (non-GFP-HB1.F3, $14.2 \pm 2.1$ and $2.3 \pm 0.3 \%$ of total cells, respectively) but not ChAT. Thus, some HB1.F3 cells had mature neuronal phenotypic markers that are routinely recognized in striatal cells (Fig. 1). HB1.F3 and GFP-HB1.F3 cells had the same morphology as evidenced by phase-contrast microscopy (Fig. 1). The doubling times of cultured HB1.F3 and GFP-HB1.F3 cells are $19.9 \pm 1.7$ and $19.8 \pm 0.9 \mathrm{~h}$, clearly indicating that GFP labeling does not affect the proliferative potencies of HB1.F3 cells. Immunocytochemical examinations also revealed the same expression pattern of neuronal markers between the cell lines [i.e., GFP-HB1.F3 cells expressed DARPP32 $(14.1 \pm 1.3 \%)$ and TH $(2.0 \pm 0.5 \%)$ but negligible ChAT, which did not significantly differ from nonGFP-HB1.F3 cells], thus suggesting that GFP labeling did not alter the phenotypic features of the cells except for GFP expression. The rate of strong GFP expression, which gradually decreased in vitro over 3 months, was $27.1 \pm 1.5 \%$, although the initial GFP expression rate was $>90 \%$ (Fig. 1). 

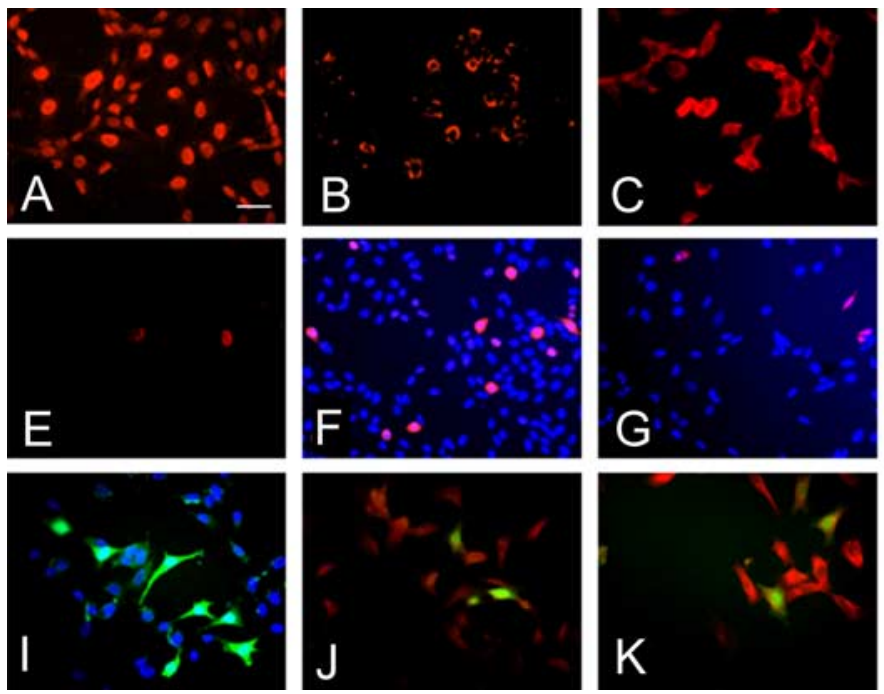

Figure 1. Phenotypic characterization of HB1.F3 cells and GFP-HB1.F3 cells in vitro. Immunocytochemical evaluation of HB1.F3 cells revealed that several cells were positive for nestin, human nuclei, HuD, and $\beta$-tubulin III antibody, some stained for MAP2, and some rarely labeled with NeuN. Some cells were DARPP32 and TH positive, thus indicating that the cells display the characteristics of striatal neurons, although their morphological immature appearance suggests an early progenitor cell type. Parallel immunocytochemical evaluations of GFP-HB1.F3 cells revealed the same expression of phenotypic markers and morphology found in non-viral labeled HB1.F3 cells. $\boldsymbol{A}$, Nestin; $\boldsymbol{B}$, human nuclei; $\boldsymbol{C}, \mathrm{HuD} ; \boldsymbol{D}, \mathrm{MAP2} ; \boldsymbol{E}, \mathrm{NeuN} ; \boldsymbol{F}, \mathrm{DARPP} 32$ (red) and Hoechst33342 (blue); $\boldsymbol{G}$, TH (red) and Hoechst33342 (blue); $\boldsymbol{H}$, phase-contrast image of HB1.F3 cells; $\boldsymbol{I}$, GFP-HB1.F3 cells (blue, Hoechst33342); J, $\beta$-tubulin III (red); $\boldsymbol{K}$, MAP2 (red); $\boldsymbol{L}$, phase-contrast image of GFP-HB1.F3 cells. Scale bar, $30 \mu \mathrm{m}$.

\section{Behavioral amelioration of HB1.F3 cell-transplanted rats}

Accuscan tests demonstrated a near normal spontaneous locomotor activity in HB1.F3-transplanted rats at 2 and 4 weeks after transplantation in all eight categories, whereas a significant hypoactivity was detected in vehicle-treated, dead HB1.F3transplanted, CM and single SCF-injected rats, but not continuous SCF delivery at both test periods (for statistics, see Table 1). Rats receiving continuous SCF infusion demonstrated partial amelioration compared with vehicle-treated rats but not the other control groups (Table 1). Cylinder test revealed that the ratio of the affected forelimb use of HB1.F3-transplanted rats (41.2 \pm 3 and $41.9 \pm 2.3 \%$ to total forelimb use at 2 and 4 weeks after transplantation) was significantly higher than that of vehicle-treated, dead cell-transplanted, CM and single SCFinjected rats ( 2 weeks, $25.8 \pm 1.8,20.0 \pm 2.7,23.7 \pm 3.5$, and $26.3 \pm 1.8 \%$; 4 weeks, $22.5 \pm 3.9,18.1 \pm 3.0,18.1 \pm 3.8$, and $19.4 \pm 3.6 \%$, respectively) but not that of continuously SCFinfused rats $(28.1 \pm 5.4$ and $28.1 \pm 5.0 \%)$. However, SCF continuous infusion did not significantly differ from the other control groups, thus indicating that forelimb akinesia was robustly ameliorated by transplanted HB1.F3 cells and only partially by osmotic minipump SCF delivery (repeated-measures ANOVA, $F_{(5,42)}=7.2 ; p<0.0001$; and post hoc $t$ tests of $p$ values $<0.05$ for both test periods) (Fig. $2 A$ ). The number of apomorphineinduced rotations of transplanted rats was significantly lower $(0.86 \pm 0.94$ and $1.3 \pm 0.52$ turns/min at 2 and 4 weeks after transplantation) than that of vehicle-treated, dead celltransplanted, CM and single SCF-injected rats (2 weeks, $5.3 \pm$ $0.54,5.3 \pm 0.92,5.4 \pm 0.96$, and $5.0 \pm 0.75$; 4 weeks, $5.5 \pm 0.44$, $6.98 \pm 0.92,6.4 \pm 0.97$, and $6.4 \pm 0.75 \mathrm{turns} / \mathrm{min}$, respectively) but not that of continuously SCF-infused rats $(4.3 \pm 0.99$ and $4.3 \pm 1.4$ turns $/ \mathrm{min}$ ). Similar to cylinder test results, SCF continuous infusion did not significantly differ from the other control groups, thus indicating that 6-OHDA-induced dopamine receptor hypersensitivity was maximally attenuated by transplanted
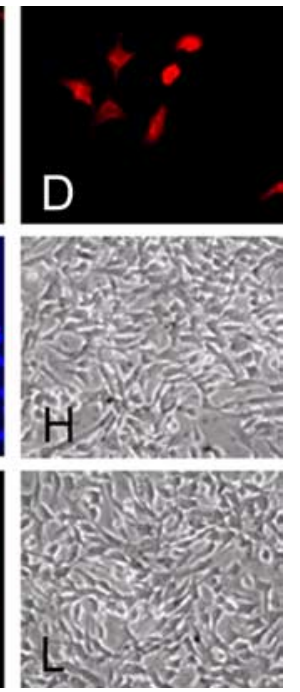

HB1.F3 cells but only moderately by osmotic minipump SCF delivery (repeatedmeasures ANOVA, $F_{(5,42}=5.4 ; p=$ 0.0006; post hoc $t$ tests of $p$ values $<0.05$ for both test periods) (Fig. 2B).

\section{Preservation of nigrostriatal dopaminergic} system and expression of $c$-kit and TrkB in the striatum

$\mathrm{TH}$ staining of the striatum and the $\mathrm{SNc}$, analyzed in three different coronal section levels, demonstrated that the dopaminergic nigrostriatal system of the HB1.F3-transplanted rats was significantly preserved in all levels examined $\left(\mathrm{SNc}, F_{(5,42)}=130, p<\right.$ $0.0001, p$ values $<0.05,54.5 \pm 4.0,48.9 \pm$ 3.4 , and $57.8 \pm 3.4 \%$ to the intact side at the level of $-4.8,-5.3$, and $-5.8 \mathrm{~mm}$ to bregma; striatum, $F_{(5,42)}=45, p<0.0001$, $p$ values $<0.05,36.6 \pm 2.4,42.7 \pm 1.8$, and $28.9 \pm 1.7 \%$ to the intact side at the level of $0.5,-0.5$, and $-1.5 \mathrm{~mm}$ to bregma) compared with that of all the other control rats (vehicle SNc, $4.8 \pm 0.7$ $5.1 \pm 0.7$, and $16.7 \pm 2.3 \%$, striatum, $21.1 \pm 1.6,17.6 \pm 2.2$, and $8.4 \pm 1.1 \%$; dead HB1.F3 SNc, $4.4 \pm 0.4,4.7 \pm 0.5$, and $15.9 \pm 1.7 \%$; striatum, $17.2 \pm 1.5,15.4 \pm$ 1.5 , and $9.0 \pm 0.8 \% ; \mathrm{CM} \mathrm{SNc}, 4.3 \pm 0.4$ $4.3 \pm 0.6$, and $16.1 \pm 1.6 \%$, striatum, $16.6 \pm 1.3,13.6 \pm 2.0$, and $9.2 \pm 1.4 \%$; single SCF SNc, $5.4 \pm 0.6,4.8 \pm 1.0$, and $16.2 \pm$ $1.7 \%$, striatum, $17.9 \pm 2.1,13.0 \pm 1.9$, and $8.3 \pm 1.0 \%$; continuous SCF SNc, $28.4 \pm 3.5,19.5 \pm 2.1$, and $32.0 \pm 3.0 \%$; striatum, $27.3 \pm 2.8,24.0 \pm 3.2$, and $15.7 \pm 2.3 \%$ ) (Fig. $3 A-G$ ). In addition, rats receiving continuous SCF infusion displayed significant preservation of nigrostriatal systems compared with vehicletreated, dead HB1.F3-transplanted, CM and single SCF-injected lesioned rats ( $p$ values $<0.05$ ). The expression of the SCF receptor c-kit and the BDNF receptor TrkB on TH-positive fibers in the striatum was also confirmed immunohistochemically by confocal microscopy (Fig. 3H-M).

\section{Graft survival with MAP2 immunoreactivity and synapse formation}

Graft survival rates at day 3, week 1, week 2, and week 4 after transplantation are $11.2 \pm 1.4,4.7 \pm 0.6,1.7 \pm 0.2$, and $1.1 \pm$ $0.2 \%$, respectively. Many GFP/human nuclei double-positive cells remained at the transplanted site at day 3 after transplantation which immunostained positively with nestin or MAP2 but rarely $\mathrm{TH}$ (Fig. 4A). Most cells remained at the transplanted site at 4 weeks after transplantation, characterized as a cluster with GFP expression. Some transplanted cells expressed MAP2, although there were no TH-positive transplanted cells in the striatum at this time point. Furthermore, some GFP-labeled cells were decorated with synaptophysin (Fig. $4 B-D$ ). As noted above, we acknowledge that GFP expression in vitro wanes over time, raising the possibility that some of the transplanted cells that eventually expressed weak or lack GFP expression were not included in our counts of cell survival. However, our cell count strategy reflects a conservative approach in that only cells with strong GFP expression were included. Because a dynamic (good to moderate to low) GFP-positive graft survival over transplant maturation periods is recognized, such conservative cell count approach closely approximates the general graft survival trend of this cell line. 
Table 1. Near normal spontaneous locomotor activity in 6-0HDA-lesioned rats that received HB1.F3 cell grafts

\begin{tabular}{|c|c|c|c|c|c|c|c|c|c|}
\hline Posttransplant period & Group & $\mathrm{HA}$ & TDT & MN & MT & RT & VA & VMN & VMT \\
\hline \multirow[t]{6}{*}{ Week 2} & HB1.F3 & $7331 \pm 295^{* *}$ & $2903 \pm 182^{*}$ & $216 \pm 11^{* *}$ & $297 \pm 12^{*}$ & $3303 \pm 12^{*}$ & $2023 \pm 88^{* *}$ & $121.3 \pm 13^{*}$ & $1425 \pm 103^{*}$ \\
\hline & Vehicle & $3486 \pm 645$ & $1197 \pm 292$ & $120 \pm 24$ & $142 \pm 34$ & $3457 \pm 34$ & $716 \pm 261$ & $60 \pm 23$ & $665 \pm 264$ \\
\hline & Dead HB1.F3 & $4415 \pm 539$ & $1737 \pm 245$ & $167 \pm 11$ & $188 \pm 28$ & $3412 \pm 28$ & $630 \pm 38$ & $57 \pm 24$ & $609 \pm 125$ \\
\hline & $\mathrm{CM}$ & $3531 \pm 532$ & $1661 \pm 291$ & $154 \pm 10$ & $215 \pm 25$ & $3385 \pm 25$ & $590 \pm 59$ & $55 \pm 8$ & $734 \pm 178$ \\
\hline & Single SCF & $2484 \pm 684$ & $1531 \pm 170$ & $153 \pm 23$ & $161 \pm 31$ & $3439 \pm 31$ & $639 \pm 77$ & $59 \pm 14$ & $795 \pm 128$ \\
\hline & Continuous SCF & $3556 \pm 384$ & $2126 \pm 436$ & $148 \pm 16.7$ & $253 \pm 47^{* * * *}$ & $3347 \pm 47^{* * *}$ & $937 \pm 49$ & $80 \pm 16$ & $1020 \pm 93$ \\
\hline \multirow[t]{6}{*}{ Week 4} & HB1.F3 & $7564 \pm 454^{*}$ & $3141 \pm 302^{*}$ & $260 \pm 15^{*}$ & $323 \pm 23^{*}$ & $3276 \pm 23^{*}$ & $1388 \pm 162^{*}$ & $106 \pm 13^{*}$ & $960 \pm 64^{*}$ \\
\hline & Vehicle & $4300 \pm 474$ & $1437 \pm 232$ & $185 \pm 14$ & $173 \pm 26$ & $3426 \pm 26$ & $749 \pm 144$ & $64 \pm 9$ & $568 \pm 103$ \\
\hline & Dead HB1.F3 & $3689 \pm 337$ & $1300 \pm 147$ & $143 \pm 16$ & $126 \pm 24$ & $3474 \pm 24$ & $642 \pm 90$ & $64 \pm 11$ & $604 \pm 92$ \\
\hline & $\mathrm{CM}$ & $3531 \pm 532$ & $1198 \pm 190$ & $135 \pm 10$ & $171 \pm 25$ & $3429 \pm 25$ & $690 \pm 210$ & $66 \pm 13$ & $608 \pm 116$ \\
\hline & Single SCF & $3252 \pm 376$ & $1833 \pm 179$ & $183 \pm 18$ & $170 \pm 24$ & $3430 \pm 24$ & $534 \pm 175$ & $69 \pm 10$ & $664 \pm 87$ \\
\hline & Continuous SCF & $6187 \pm 382^{* * * *}$ & $2951 \pm 683$ & $212 \pm 13$ & $317 \pm 64^{* * * *}$ & $3283 \pm 64^{* * *}$ & $986 \pm 286$ & $88 \pm 18$ & $867 \pm 132$ \\
\hline
\end{tabular}

All the data were obtained using the Accuscan locomotor activity monitor. Lesioned rats that received HB1.F3 cell grafts displayed significantly higher activity (i.e., near normal levels) than vehicle-treated, dead HB1.F3-transplanted, CM and single SCF-injected lesioned rats in all parameters measured, including the following: $\mathrm{HA}$, horizontal activity; TD, total distance; MN, movement number; $M T$, movement time; RT, rest time; VA, vertical activity; VMN, vertical movement number; VMT, vertical movement time. Lesioned rats with continuous SCF infusion displayed significantly higher activity than vehicle-treated lesioned rats in some parameters. Data are shown as raw data $\pm S E$. ${ }^{*} p<0.05$ versus control rats, except for rats receiving continuous SCF infusion; ${ }^{* *} p<0.05$ versus all control rats; ${ }^{* *} p<0.05$ versus vehicle-treated lesioned rats using ANOVA.

A

Cylinder test

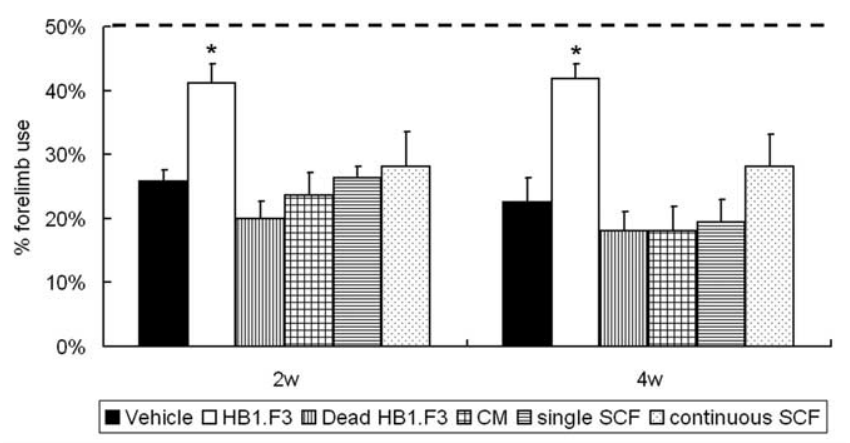

$\mathbf{B}$

Apomorphine-induced rotations

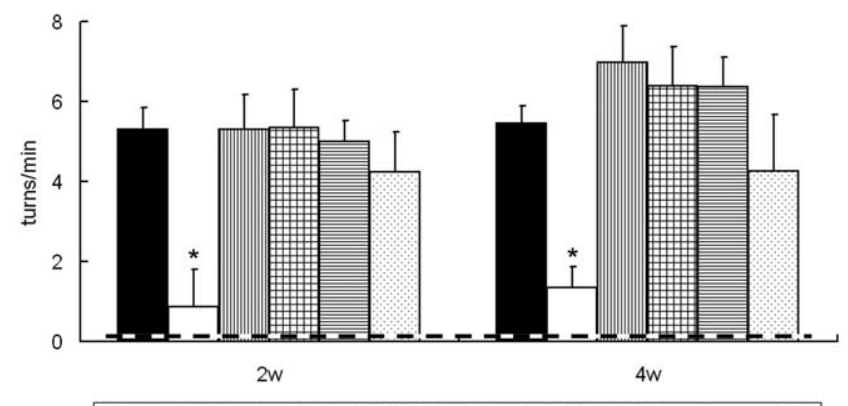

Vehicle $\square$ HB1.F3 四 Dead HB1.F3 田CM 目single SCF $\square$ continuous SCF

Figure 2. HB1.F3 cell grafts ameliorate forelimb akinesia and apomorphine-induced rotations. $\boldsymbol{A}$, Cylinder test revealed improved forelimb akinesia in lesioned rats that received HB1.F3 cell grafts compared with control rats, except for rats receiving continuous SCF infusion at 2 and 4 weeks after transplantation. Dashed line indicates performance of control (i.e., naive non-6$\mathrm{OHDA}$-lesioned age-matched rats). Data are shown as mean $\pm \mathrm{SE}$ ratio of the affected forelimb use. ${ }^{*} p<0.05$ versus control rats except for rats receiving continuous SCF infusion. $\boldsymbol{B}$, The number of apomorphine-induced rotations in lesioned rats that received HB1.F3 cell grafts significantly decreased compared with control rats, except for rats receiving continuous SCF infusion at 2 and 4 weeks. Dashed line indicates performance of control, nonlesioned rats. Data are shown as mean \pm SE rotations per minute. ${ }^{*} p<0.05$ versus control rats, except for rats receiving continuous $S C F$ infusion.

Enhanced neurogenesis in the SVZ

To test our hypothesis that HB1.F3 cell graft-mediated neurogenesis participated in the observed functional recovery, we performed BrdU injection from 2 weeks up to 4 weeks after lesion, corresponding to the timing of behavioral improvement. BrdU/ Dcx double-positive cells were counted in the SVZ adjacent to the transplanted site to demonstrate neurogeneic activity of HB1.F3 cell grafts. The number of double-positive cells in the SVZ of the HB1.F3 cell-transplanted rats was significantly increased (142 \pm $6.9 \%$ of the intact side) compared with that in vehicle-treated and CM-injected lesioned rats $(122 \pm 2.2$ and $120 \pm 6.9 \%$, respectively; $F_{(5,42)}=4.4 ; p=0.0027 ; p$ values $\left.<0.05\right)($ Fig. $4 E-I)$ but not that in dead HB1.F3-transplanted, single SCF and continuous SCF-treated lesioned rats $(123 \pm 3.2,128 \pm 0.6$, and $134 \pm$ $5.6 \%$, respectively). These in vivo results demonstrate neuroprotective and neurogeneic effects of transplanted HB1.F3 cells. We then pursued in vitro experiments to further reveal the mechanisms underlying these therapeutic benefits of HB1.F3 cells.

\section{In vitro study}

Neuroprotection by HB1.F3-derived culture media against 6-OHDA neurotoxicity

Dose- and time-dependent 6-OHDA neurotoxicity to SH-SY5Y cells was confirmed by immunocytochemical investigations and MTT assay. MTT assay revealed that cells with 6-OHDA exposure for $24 \mathrm{~h}$ displayed more reduced MTT activity in a doseresponsive manner than those with 6-OHDA exposure for $12 \mathrm{~h}$ (repeated-measures ANOVA; $F_{(3,26)}=275 ; p<0.0001 ; 12 \mathrm{~h}$, $88.2 \pm 4.4,70.4 \pm 3.1$, and $10.3 \pm 1.3 \% ; 24 \mathrm{~h}, 82.7 \pm 5.2,43.9 \pm$ 3.9 , and $3.8 \pm 0.6 \%$ of the untreated control with 1,10 , and $40 \mu \mathrm{M}$ 6 -OHDA, respectively; $p$ values $<0.01$ ) (Fig. $5 A$ ). Furthermore, the number of surviving cells against 6-OHDA exposure for $24 \mathrm{~h}$ detected by $\mathrm{TH} /$ nuclear staining were significantly more than that with 6-OHDA exposure for $12 \mathrm{~h}$ (repeated-measures ANOVA; $\left.F_{(3,20)}=114.5 ; p<0.0001\right)$ in a dose-responsive manner $(12 \mathrm{~h}, 86 \pm 5,59 \pm 4.7$, and $26 \pm 1.7 \% ; 24 \mathrm{~h}, 81 \pm 4,38 \pm 3.5$, and $7 \pm 0.8 \%$ of the untreated control with 1,10 , and $40 \mu \mathrm{M}$ 6 -OHDA, respectively; $p$ values $<0.01$ ) (Fig. $5 B$ ). Based on these present results and those from previous studies (Maruyama et al., 2001, 2002; Yasuhara et al., 2004, 2005), $40 \mu \mathrm{M}$ 6-OHDA for $24 \mathrm{~h}$ was used in subsequent studies. In addition, immunocytochemical evaluation of SH-SY5Y cells revealed that most cells were well stained with antibodies against MAP2, TH, and human nuclei and rarely stained with anti-nestin antibody, indicating the dopaminergic neuronal phenotype of this cell line (Fig. 5C-E).

We then proceeded to explore the neuroprotective effects of the CM against 6-OHDA toxicity. MTT activity of 6-OHDAexposed SH-SY5Y cells treated with the CM was significantly higher than those cells without $\mathrm{CM}$ treatment (repeatedmeasures ANOVA; $F_{(1,13)}=253 ; p<0.0001$; with and without CM treatment, $53 \pm 6.8$ and $5.2 \pm 0.8 \%$ of the untreated control; 

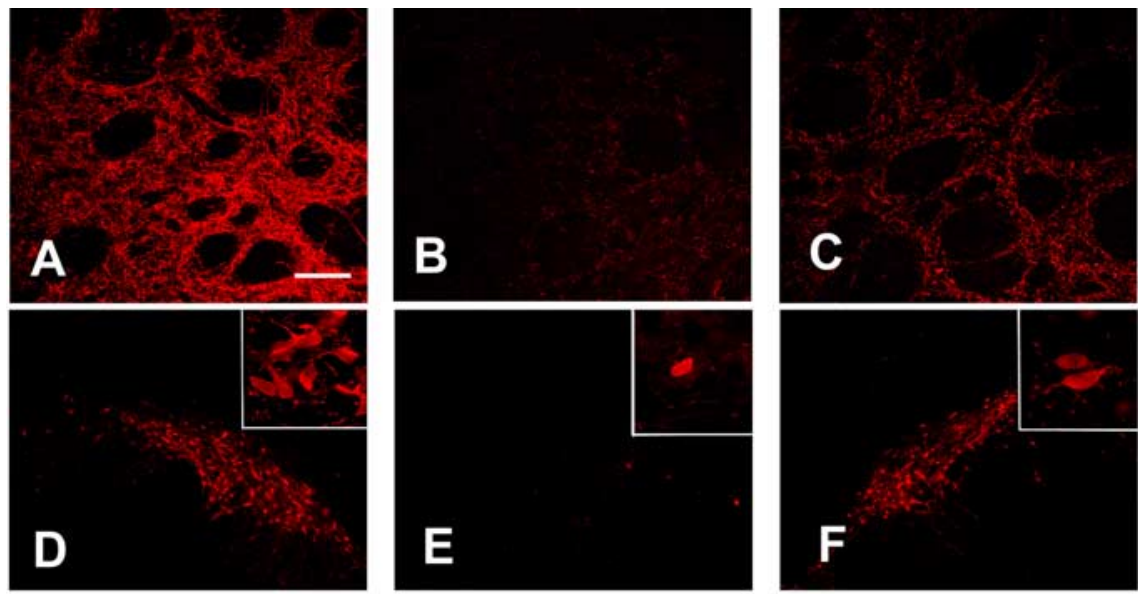

G

TH positive cells in the SNc

Density of TH positive fibers in the striatum
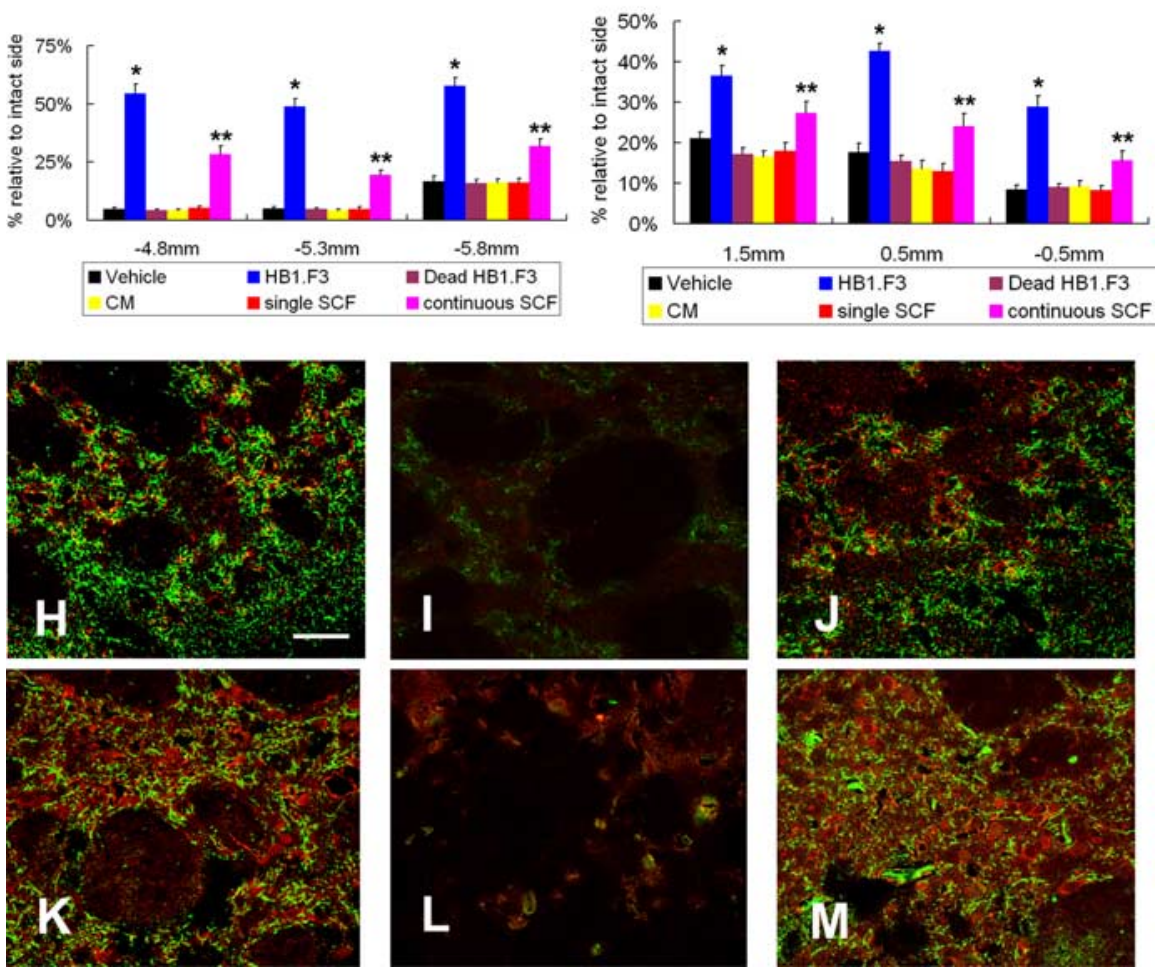

Figure 3. HB1.F3 cell grafts preserve TH-positive fibers in the striatum and neurons in the SNc and normalize c-kit/TrkB expression in the striatum. $\boldsymbol{A}-\boldsymbol{F}$, TH-positive fibers in the striatum and neurons in the SNc of rats that received HB1.F3 cell grafts were markedly preserved $(\boldsymbol{C}, \boldsymbol{F})$ compared with vehicle-treated rats $(\boldsymbol{B}, \boldsymbol{E})$. Intact striatum $(\boldsymbol{A})$ and intact SNc $(\boldsymbol{D})$ show normal TH-positive fibers and neurons, respectively. Insets are representative higher magnifications of TH-positive cells in $\boldsymbol{D}-\boldsymbol{F}$. Scale bar: $\boldsymbol{A}-\boldsymbol{C}$ (captured by confocal microscopy), $50 \mu \mathrm{m} ; \boldsymbol{D}-\boldsymbol{F}, 100 \mu \mathrm{m}$; insets in $\boldsymbol{D}-\boldsymbol{F}, 10 \mu \mathrm{m}$. G, Left, TH-positive fibers at three different coronal levels in the striatum were analyzed with a computerized image analysis system. Lesioned rats transplanted with HB1.F3 cells exhibited significantly more TH-positive fibers than all other lesioned rats. Rats with continuous SCF infusion also demonstrated significantly more TH-positive neurons than vehicle-treated, dead HB1.F3-transplanted, CM and single SCF-injected lesioned rats. Data are shown as mean \pm SE values expressed as percentages relative to the intact side. ${ }^{*} p<0.05$ versus all other rats; ${ }^{* *} p<0.05$ versus vehicle-treated, dead HB1.F3-transplanted, CM and single SCF-injected lesioned rats. G, Right, THpositive fibers at three different levels in the striatum were analyzed with a computerized image analysis system. Lesioned rats transplanted with HB1.F3 cells demonstrated significantly more TH-positive fibers than all other lesioned rats. Rats with continuous SCF infusion also demonstrated significantly more TH-positive fibers than vehicle-treated, dead HB1.F3-transplanted, CM and single SCF-injected lesioned rats. Data are shown as mean values \pm SE expressed as percentages relative to the intact side. ${ }^{*} p<0.05$ versus all other rats; ${ }^{* *} p<0.05$ versus vehicle-treated, dead HB1.F3-transplanted, CM and single SCF-injected lesioned rats. $\boldsymbol{H}-\boldsymbol{M}$, The expression of the SCF receptor c-kit and the BDNF receptor TrkB was confirmed immunohistochemically in the intact and transplanted striatum by confocal microscopy. Yellowish fibers indicate colabeling of TH-positive fibers (green) with one of the receptors (red). The expression of both receptors in the striatum of vehicle-treated lesioned rats was difficult to identify because of severely reduced TH-positive fibers. $\boldsymbol{H}-\boldsymbol{J}$, TH (green) and c-kit (red). $\boldsymbol{K}-\boldsymbol{M}$, TH (green) and TrkB (red). $\boldsymbol{H}$ and $\boldsymbol{K}$ correspond to intact striatum, $\boldsymbol{I}$ and $\boldsymbol{L}$ represent vehicle-treated lesioned striatum, and $\boldsymbol{J}$ and $\boldsymbol{M}$ are from HB1.F3-transplanted lesioned striatum. Scale bar. $30 \mu \mathrm{m}$ $p$ values $<0.01$ ) (Fig. $5 F$ ). In addition, there was a tendency to increase MTT activity of CM-treated SH-SY5Y cells without 6-OHDA exposure compared with the untreated control ( $p$ values $=0.0751)$. Immunocytochemical results supported the MTT data, in that the number of surviving CM-treated SH-SY5Y cells was significantly higher than that of non-CMtreated cells after 6-OHDA exposure (repeated-measures ANOVA; $F_{(1,10)}=$ $10.3 ; p=0.0093$; with and without $\mathrm{CM}$ treatment, $20 \pm 2.4$ and $7.1 \pm 0.8 \%$ of the untreated control; $p$ values $<0.01$ ) (Fig. $5 G)$. In addition, the number of CMtreated SH-SY5Y cells without 6-OHDA exposure tended to increase compared with the untreated control ( $p$ values $=$ 0.0904) (Fig. $5 G-K$ ).

In contrast, coculture of fixed HB1.F3 cells did not demonstrate any detectable neuroprotective effects in 6-OHDAexposed SH-SY5Y cells $\left(F_{(1,10)}=2.8 ; p<\right.$ 0.01 ; with and without coculture, $11.3 \pm$ 1.7 and $10.4 \pm 1.1 \%$ relative to untreated control; $p$ values $=0.375$ ), suggesting that HB1.F3 cells exerted neuroprotective effects via a mechanism that did not involve cell-tocell contact.

Secretion of SCF and BDNF from HB1.F3 cells in vitro

The lack of evidence implicating a cell-tocell contact-mediated neuroprotection prompted us to examine the mechanism of neurotrophic factor secretion by HB1.F3 cells. ELISA revealed that secretion of SCF and BDNF from HB1.F3 cells were $194.2 \pm$ 8.4 and $28.9 \pm 1.9 \mathrm{pg} / 10^{6}$ cells per day, significantly higher than those from SH-SY5Y cells, $0.1 \pm 0.1$ and $1.9 \pm 0.3 \mathrm{pg} / 10^{6}$ cells per day $(n=10$ in each group; $p<0.001)$. However, GDNF and VEGF were not detected in the CM of HB1.F3 and SH-SY5Y cells. The CM from hMPCs exhibited significantly larger amount of VEGF $(2.74 \pm 0.22 \mathrm{ng} /$ $10^{6}$ cells per day $)$ and SCF $(248 \pm 11.8 \mathrm{pg} /$ $10^{6}$ cells per day) with a modest amount of $\operatorname{BDNF}\left(4.74 \pm 1.1 \mathrm{pg} / 10^{6}\right.$ cells per day) but negligible GDNF.

\section{Neutralization and immunoprecipitation}

of SCF block neuroprotection

To confirm which trophic factor in the CM plays an important role in the neuroprotection, anti-SCF and anti-BDNF antibodies were used. Anti-SCF antibody or SCF removal by immunoprecipitation, but not anti-BDNF antibody, significantly blocked the neuroprotective effects of the CM in that significantly low MTT activities were detected in these 6-OHDAexposed cells treated with $\mathrm{CM}$ plus the anti-SCF antibody $\left(\right.$ ANOVA; $F_{(10,55)}=195$; 
$p<0.0001 ; p$ values $<0.01$ ) (Table 2). Immunocytochemical results mimicked the MTT data as evidenced by significantly low number of surviving 6-OHDA-exposed cells treated with both the CM and anti-SCF antibody or SCF-removed CM by immunoprecipitation $\left(\mathrm{ANOVA} ; F_{(10,55)}=169 ; p<\right.$ 0.0001 ; $p$ values $<0.01$ ) (Table 2).

\section{Direct neuroprotective effects of SCF} against 6-OHDA neurotoxicity

With the demonstration of anti-SCF antibody neutralizing the neuroprotective effects of the CM harvested from HB1.F3 cells, we next assessed the direct neuroprotective effects of SCF itself. MTT assay revealed the neuroprotective effects of recombinant human SCF in 6-OHDA-exposed SH-SY5Y cells, which was completely neutralized by anti-SCF antibody (ANOVA; $F_{(6,49)}=326$; $p<0.0001)$. Treatment with $500 \mathrm{pg} / \mathrm{ml}$ and $5 \mathrm{ng} / \mathrm{ml} \mathrm{SCF}$ in 6-OHDA-exposed cells resulted in cell viability of $27.7 \pm 2.4$ and $26.1 \pm 2.1 \%$, respectively, relative to untreated control, versus $10.4 \pm 2.8$ and $7.5 \pm$ $1.6 \%$ in 6-OHDA-exposed untreated cells and 6-OHDA-exposed cells treated with both SCF and anti-SCF antibody, respectively ( $p$ values $<0.05$ ) (Fig. 6). Furthermore, immunocytochemical investigation using $\mathrm{TH}$ staining revealed that the number of SCF-treated 6-OHDA-exposed cells was significantly higher than that of 6-OHDAexposed untreated cells and 6-OHDAexposed cells with both SCF and anti-SCF antibody (ANOVA; $F_{(6,35)}=203 ; p<$ $0.0001 ; 500 \mathrm{pg} / \mathrm{ml}$ and $5 \mathrm{ng} / \mathrm{ml} \mathrm{SCF}$-treated 6-OHDA-exposed cells, $25.4 \pm 2.0$ and $21.7 \pm 2.7 \%$ relative to untreated control compared with $5.0 \pm 0.8$ in 6-OHDAexposed untreated cells and $4.8 \pm 0.8 \%$ in 6-OHDA-exposed cells with both SCF and anti-SCF antibody; $p$ values $<0.05$ ) (Fig. 6). There were no significant differences between $500 \mathrm{pg} / \mathrm{ml}$ and $5 \mathrm{ng} / \mathrm{ml} \mathrm{SCF}$ treatment in both MMT assay and immunocytochemical evaluations.
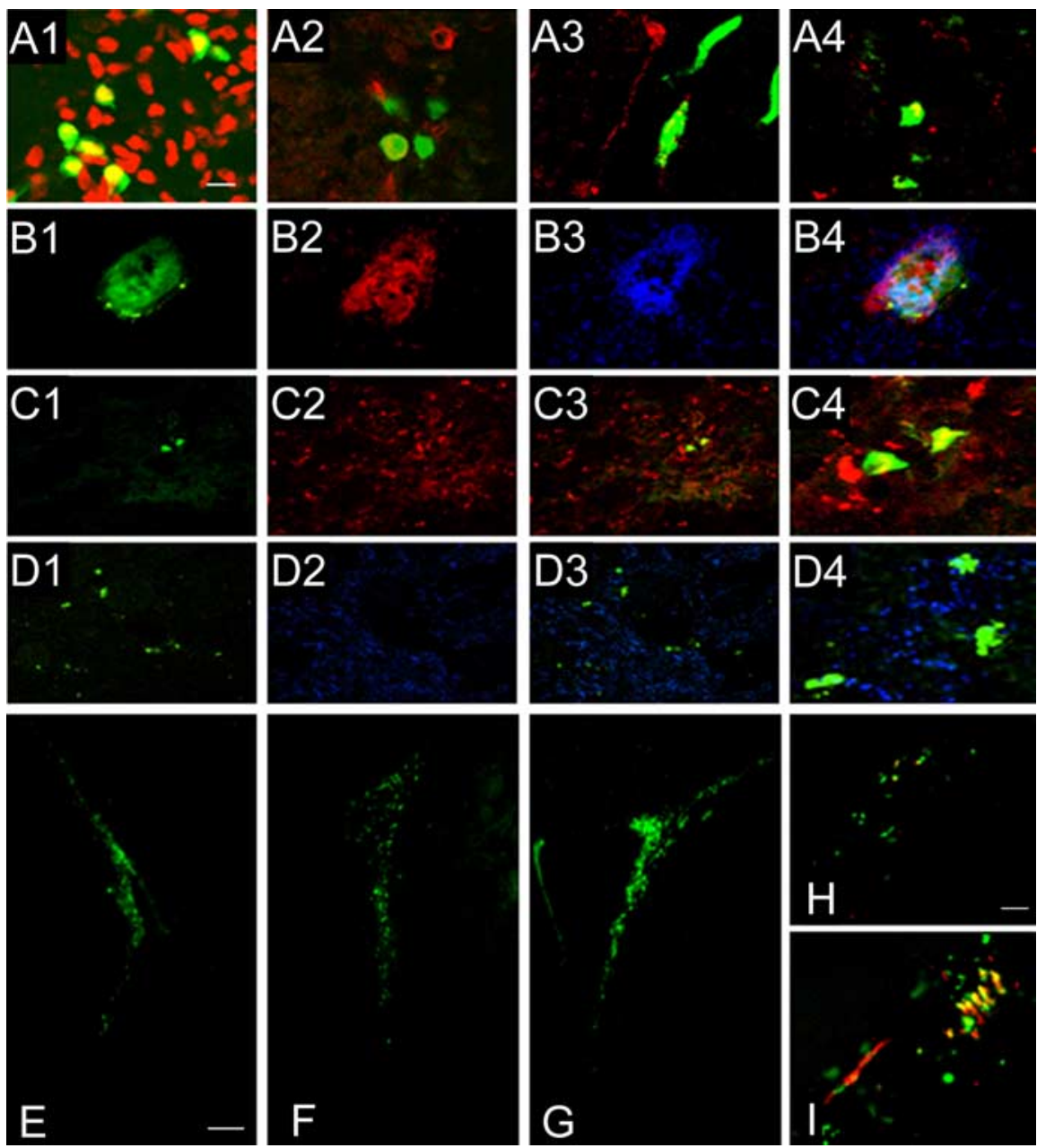

Figure 4. HB1.F3 cell grafts survive in the lesioned striatum and enhance neurogenesis in the SVZ. A, Confocal microscopy revealed that many transplanted GFP-positive cells were well stained with anti-human nuclei antibody $(\boldsymbol{A} \mathbf{1})$ with nestin $(\boldsymbol{A} \mathbf{2})$, MAP2 (A3), and rarely TH expression (A4) at $3 \mathrm{~d}$ after transplantation. Scale bar, $10 \mu \mathrm{m} . \boldsymbol{B}-\boldsymbol{D}$, Almost all of the transplanted HB1.F3 cells were found at the original implantation site at 4 weeks after transplantation and positively stained with anti-human nuclei antibody (B2) and Hoechst33342 (B3) with modest GFP expression (B1; $\boldsymbol{B} 4$, triple-merged image). Some GFP-labeled HB1.F3-transplanted cells (C1) were MAP2 positive ( $\mathbf{C} ; \mathbf{C}$, merged image; $\mathbf{C}$, high magnification). In addition, some GFPlabeled HB1.F3 cells (D1) were decorated with synaptophysin-positive terminals (D2), suggesting synapse formation (D3, merged image; $\mathbf{D 4}$, high magnification). Scale bar: $\mathbf{C}, \mathbf{D 4}, 6 \mu \mathrm{m}$; all other panels, $30 \mu \mathrm{m}$. The images in $\boldsymbol{C}$ and $\boldsymbol{D}$ were captured using a confocal microscope. $\boldsymbol{E}-\boldsymbol{G}$, BrdU staining of the SVZ of the intact side $(\boldsymbol{E})$, vehicle-treated lesioned side $(\boldsymbol{F})$, and transplanted lesioned side $(\boldsymbol{G})$ revealed enhanced neurogenesis induced by HB1.F3 cell transplantation. Scale bar, $80 \mu \mathrm{m}$. $\boldsymbol{H}, \boldsymbol{I}$, Many newly formed cells (BrdU, green) in the SVZ of lesioned rats that received HB1.F3 cell grafts, but not those from vehicle-treated lesioned rats, were doublecortin (red) colabeled (yellow) (H, vehicle-treated rats; $\boldsymbol{I}$, HB1.F3 cell-transplanted rats). Scale bar, $30 \mu \mathrm{m}$.

\section{Mechanisms underlying \\ SCF neuroprotection}

In addition to the participation of neurotrophic factor secretion in HB1.F3 cell neuroprotection, we examined the involvement of an anti-apoptotic mechanism. TUNEL staining revealed that CM treatment in 6-OHDA-exposed cells significantly reduced the ratio of apoptotic cells compared with untreated 6-OHDA-exposed cells (repeated-measures ANOVA; $F_{(1,6)}=78 ; p=0.0001 ; 3.1 \pm$ 0.7 and $17.4 \pm 1.5 \%$ of Hoechst33342-positive cells; $p$ values $<0.001$ ) (Fig. $7 A-C$ ), indicating that HB1.F3 cells, via secretion of neurotrophic factors (i.e., SCF) in the supernatant, exerted anti-apoptotic effects.

As shown in a previous report (Cohen et al., 1994), c-kit and TrkB are expressed to some extent in SH-SY5Y cells under normal conditions. In the present study, c-kit expression of 6-OHDAexposed SH-SY5Y cells was documented immunocytochemically. c-kit expression of SH-SY5Y cells with $0,1,10$, and $40 \mu \mathrm{m}$ 6-OHDA exposure for $24 \mathrm{~h}$ was $22.8 \pm 1.4,31.7 \pm 1.8,26.8 \pm 1.1$, and $13.6 \pm$ $2.4 \%$ of total cells, respectively, indicating significant upregulation of c-kit expression in SH-SY5Y cells exposed to low dose $(1 \mu \mathrm{M})$ 6-OHDA $\left(\right.$ ANOVA; $F_{(3,16)}=19.8 ; p<0.0001 ; p$ values $\left.=0.0182\right)$ (Fig. 7D-G). These data indicate that 6-OHDA triggered c-kit upregulation in SH-SY5Y cells, which likely enhanced SCF-c-kit binding. In addition, the BDNF receptor TrkB was also strongly expressed on SH-SY5Y cells (Fig. 7H). Such receptor upregulations might have facilitated the neuroprotective effects of SCF and BDNF. However, it appears that TrkB-BDNF binding was not optimal in the present paradigm because BDNF was shown to be only partially involved in the neuroprotection, as revealed by the antibodyneutralizing experiments (see above, Neutralization and immunoprecipitation of SCF block neuroprotection). 

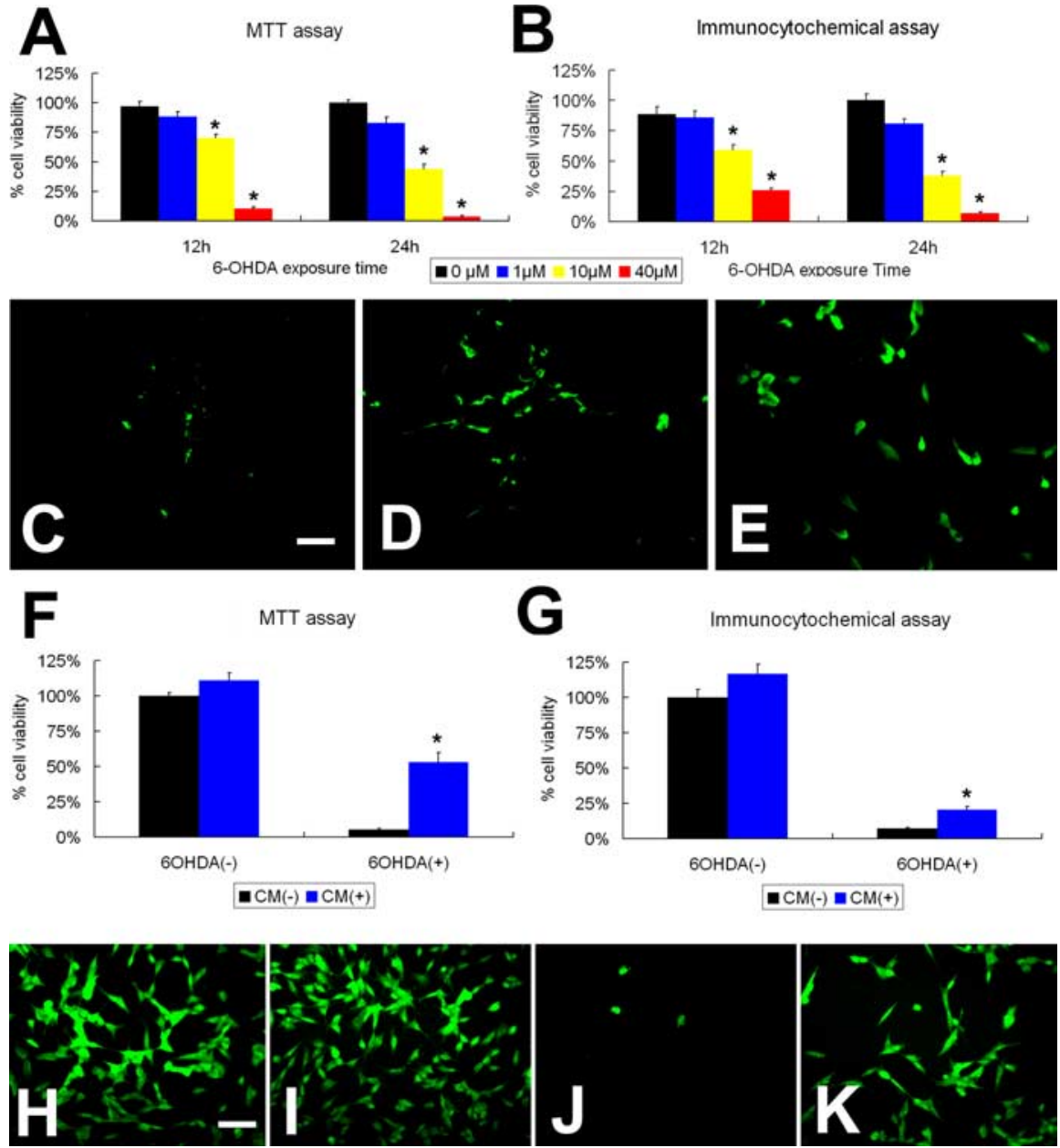

Figure 5. Neuroprotective effects of HB1.F3 cell-derived CM against 6-OHDA in cultured SHSY5Y cells. $\boldsymbol{A}, \boldsymbol{B}$, Neurotoxicity of 6-OHDA was confirmed by MTT assay and immunocytochemical (i.e., TH) evaluation. Exposure of SH-SY5Y cells to 10 or $40 \mu \mathrm{M}$ 6-0HDA resulted in a significant reduction in cell viability. As expected, 6-0HDA exposure for $24 \mathrm{~h}$ induced significantly more cell loss than that seen with $12 \mathrm{~h}$ treatment. Data are shown as percentages $\pm \mathrm{SE}$ of cell viability relative to the untreated control. ${ }^{*} p<0.01$ versus untreated SH-SY5Y cells (24h). $\mathbf{C}-\boldsymbol{E}$, Immunocytochemical investigation revealed that SH-SY5Y cells used in this study were MAP2- and TH-positive neurons with rare nestin expression, indicating the neuronal phenotypic maturity of the cells ( $\boldsymbol{C}$, nestin; D, MAP2; $\boldsymbol{E}$, TH). Scale bar, $30 \mu \mathrm{m} . \boldsymbol{F}, \mathbf{G}$, Treatment with HB1.F3-derived (M significantly blocked the 6-OHDA-induced reduction of cell viability in $\mathrm{SH}-\mathrm{SY} 5 \mathrm{Y}$ cells. In addition, $\mathrm{CM}$ treatment exhibited a tendency to increase the proliferative capacities of SH-SY5Y cells that were not exposed to 6-OHDA. Data are shown as percentages \pm SE of cell viability relative to the untreated control. ${ }^{*} p<0.01$ versus $6-0 \mathrm{HDA}$-exposed SH-SY5Y cells without CM treatment. $\boldsymbol{H}-\boldsymbol{K}$, TH staining revealed many surviving 6-OHDA-exposed SH-SY5Y cells because of CM treatment ( $\boldsymbol{H}$, no treatment; I, CM only; J, 6-OHDA only; $\boldsymbol{K}, 6-0 H D A$ with CM). Scale bar, $30 \mu \mathrm{m}$

Table 2. Neuroprotective effects of cultured media derived from HB1.F3 cells

\begin{tabular}{lcc}
\hline Group & \% viability by MTT & \% viability by IM \\
\hline CM only & $110 \pm 6.0^{* * *}$ & $116 \pm 7.2^{* * *}$ \\
IP only & $85.2 \pm 2.1^{* * *}$ & $72.3 \pm 3.6^{* * *}$ \\
6-OHDA only & $4.0 \pm 0.84^{* *}$ & $7.0 \pm 0.8^{* *}$ \\
6-OHDA + aS & $3.8 \pm 0.57^{* *}$ & $8.4 \pm 0.9^{* *}$ \\
6-OHDA + aB & $3.8 \pm 0.7^{* *}$ & $7.0 \pm 1.3^{* *}$ \\
6-OHDA + CM & $34.5 \pm 3.5^{*}$ & $28 \pm 7.2^{*}$ \\
6-OHDA + IP & $6.3 \pm 0.3^{* *}$ & $7.7 \pm 1.7^{* *}$ \\
6-OHDA + CM + aS & $11.7 \pm 0.8^{* *}$ & $12.9 \pm 0.89^{* *}$ \\
6-OHDA $+\mathrm{CM}+\mathrm{aB}$ & $21.4 \pm 1.0$ & $25.7 \pm 1.8$ \\
6-OHDA $+\mathrm{CM}+\mathrm{aS}+\mathrm{aB}$ & $11.2 \pm 0.9^{* *}$ & $8.6 \pm 1.0^{* *}$
\end{tabular}

Cultured media harvested from HB1.F3 cells exerted neuroprotection against 6-OHDA neurotoxicity in cultured SH-SY5Y cells, which was significantly negated by the administration of neutralizing anti-SCF antibody or SCFremoved CM by immunoprecipitation but not anti-BDNF antibody. CM, Culture media from HB1.F3 cells; IP, SCFremoved CM by immunoprecipitation; aS, anti-SCF antibody; aB, anti-BDNF antibody; IM, immunocytochemical evaluations based on TH staining. Data are shown as percentages $\pm S E$ of cell viability relative to the untreated control. ${ }^{*} p<0.01$ versus 6-0HDA-exposed untreated SH-SY5Y cells; ${ }^{* *} p<0.05$ versus 6-0HDA-exposed SH-SY5Y cells with CM treatment.
In our desire to determine neuroprotective downstream pathways associated with the SCF-c-kit binding, the PI3k/Akt pathway was explored by using the PI3k/ Akt inhibitor LY294002. Previously, the involvement of the PI3k/Akt pathway in SCF-c-kit binding was shown in nonneural cells (Linnekin, 1999). LY294002 treatment completely cancelled the neuroprotective effects of the $\mathrm{CM}$ and SCF against 6-OHDA toxicity (ANOVA; MTT assay, $F_{(6,41)}=50.0, p<0.0001, p$ values $<0.01$; cell survival as revealed by $\mathrm{TH}$ and Hoechst33342 staining, $F_{(6,35)}=86.7, p<$ $0.0001, p$ values $<0.01$ ) (Fig. $8 A$ ).

Based on the results above demonstrating anti-apoptotic effects of CM and SCF, and accumulating evidence implicating Bcl-2 expression in both SCF-c-kit binding and the PI3k/Akt pathway, Bcl-2 protein level was monitored using the lysates from SH-SY5Y cells collected at 3, 6, 12, and $24 \mathrm{~h}$ after 6-OHDA treatment. Repeatedmeasures ANOVA revealed significant treatment effects $\left(F_{(9,20)}=22.8 ; p<0.0001\right)$ (Fig. $8 B$ ). Single ANOVA for each post-6-OHDA time point revealed a trend at $3 \mathrm{~h}\left(F_{(9,20)}=\right.$ 2.29; $p=0.059)$ and significant treatment effects at $6 \mathrm{~h}\left(F_{(9,20)}=8.463 ; p<0.0001\right)$, $12 \mathrm{~h}\left(F_{(9,20)}=25.3 ; p<0.0001\right)$, and $24 \mathrm{~h}$ $\left(F_{(9,20)}=9.3 ; p<0.0001\right)$. Pairwise comparisons revealed that $\mathrm{Bcl}-2$ protein levels of CM- or SCF-treated 6-OHDA-exposed cells at 6,12 , and $24 \mathrm{~h}$ were significantly higher than that of untreated control ( $p$ values $<0.05)$. There were no differences in the significant Bcl-2 upregulation induced by $500 \mathrm{pg} / \mathrm{ml}$ and $5 \mathrm{ng} / \mathrm{ml} \mathrm{SCF}$ at all time points ( $p$ values $>0.05)$. Antibodyneutralizing treatment conditions using anti-SCF antibody alone, LY294002 alone, or a combination of both significantly blocked the CM-mediated Bcl-2 upregulation at 6,12 , and $24 \mathrm{~h}$ ( $p$ values $<0.05)$.

Neuroprotective effects of CM and SCF on 6-OHDA-exposed fetal rat-derived ventral mesencephalic dopaminergic neurons Phenotypic characterization of the rat fetal-derived ventral mesencephalic dopaminergic neurons used in this study revealed that these cells expressed TH strongly and c-kit only moderately (Fig. $9 A-D)$, in addition to nestin, $\beta$-tubulin III, and MAP2 but not DARPP32 or GFAP expression. The relatively modest c-kit expression in these rat fetal-derived dopaminergic neurons, as opposed to the high c-kit expression detected in human SH-SY5Y cells, might limit potential neuroprotective effects of SCF on this cell line. Indeed, treatment with CM and low-dose SCF displayed full and partial (only immunocytochemical effects) neuroprotection, respectively, against 6-OHDA toxicity, which were blocked by anti-SCF antibody or SCF removal with immunoprecipitation (Fig. 9E-I) [MTT assay, repeated-measures ANOVA, $F_{(4,15)}=$ $10.1, p=0.0004$; with and without CM treatment, $32 \pm 5.2$ and $16 \pm 1.9 \%$ of the untreated control, $p$ values $<0.05$ (Fig. 9I, left); 
Effects of SCF on SH-SY5Y neurons

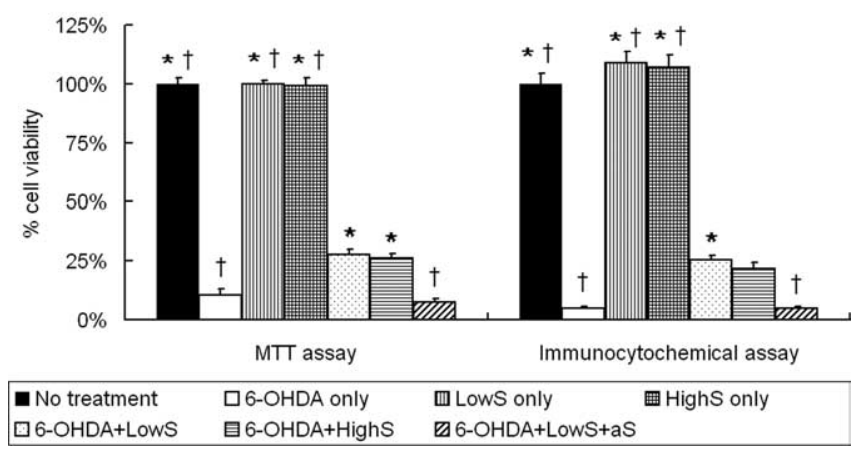

Figure 6. Neuroprotective effects of SCF against 6-OHDA neurotoxicity in cultured SH-SY5Y cells. Based on the secreted amount of SCF in the CM of HB1.F3 and the $\mathrm{ED}_{50}(2.5 \mathrm{ng} / \mathrm{ml}$; information from R \& D Systems), two doses of SCF $(500 \mathrm{pg} / \mathrm{ml}$ and $5 \mathrm{ng} / \mathrm{ml})$ were used in this study. Both doses of SCF protected cultured SH-SY5Y cells against 6-OHDA neurotoxicity, which were negated by the administration of anti-SCF antibody. However, there were no detectable proliferative effects of SCF treatment in SH-SY5Y cells when not exposed to 6-OHDA. In addition, there were no significant differences between the two doses of SCF. LowS, $500 \mathrm{pg} / \mathrm{ml} \mathrm{SCF}$; HighS, $5 \mathrm{ng} / \mathrm{ml}$ SCF; aS, anti-SCF antibody. Data are shown as percentages \pm SE of cell viability relative to the untreated control. ${ }^{*} p<0.05$ versus $6-0 \mathrm{HDA}$-exposed untreated SH-SY5Y cells. ${ }^{\dagger} p<0.05$ versus $6-0$ HDA-exposed SH-SY5Y cells with low dose of SCF treatment.

immunocytochemical assay, $F_{(4,10)}=5.2, p=0.015$; with and without CM (SCF) treatment, $34 \pm 2.1(21.2 \pm 2.0)$ and $4.2 \pm$ $2.1 \%$ of the untreated control, $p$ values $<0.05$ (Fig. 9I, right)].

\section{Discussion}

We demonstrated neuroprotective effects of HB1.F3 cells using in vivo and in vitro models of $\mathrm{PD}$. Intrastriatal transplantation of HB1.F3 cells immediately after 6-OHDA lesion in rats reduced parkinsonian motor symptoms and preserved TH nigral neurons and striatal fibers. At 1 month after transplantation, some grafted HB1.F3 cells expressed neuronal and synaptic markers, accompanied by enhanced neurogenesis in SVZ adjacent to the transplant site. In vitro studies further reveal neuronal lineage commitment of HB1.F3 cells and their ability to secrete a highly potent neurotrophic factor capable of suppressing apoptosis.

\section{HB1.F3 cell grafts attenuate parkinsonian motor symptoms}

Overall, the reductions in parkinsonian motor symptoms produced by HB1.F3 cell grafts are equal or more robust than those reported using fetal VM, NSCs, or genetically modified cells. The significant amelioration of hypoactivity in the present HB1.F3 cell-transplanted rats compared with vehicle-infused lesioned rats parallels our previous study demonstrating similar attenuation of abnormal spontaneous locomotor activity in 6-OHDAlesioned animals that received vitamin D3 treatment (Wang et al., 2001). Improvement in drug-induced rotations are observed after transplantation of human or mouse embryonic stem (ES) cells (Bjorklund et al., 2002; Ben-Hur et al., 2004; Yoshizaki et al., 2004), genetically modified cells (Kang et al., 1993; Leff et al., 1998; Chen et al., 2003), or NSCs or neural progenitor/precursor cells (Svendsen et al., 1997; Armstrong et al., 2002; Sun et al., 2003; Rafuse et al., 2005; Richardson et al., 2005; Harrower et al., 2006). Cell transplantation of rat embryonic VM cells at 2 weeks after 6-OHDA lesion did not attenuate the forelimb akinesia using the cylinder test (Dowd and Dunnett, 2004). In contrast, contralateral paw use was up 25\% in the HB1.F3 cell-grafted lesioned rats compared with vehicle-treated lesioned animals. The present same-day lesion transplant paradigm likely contrib-
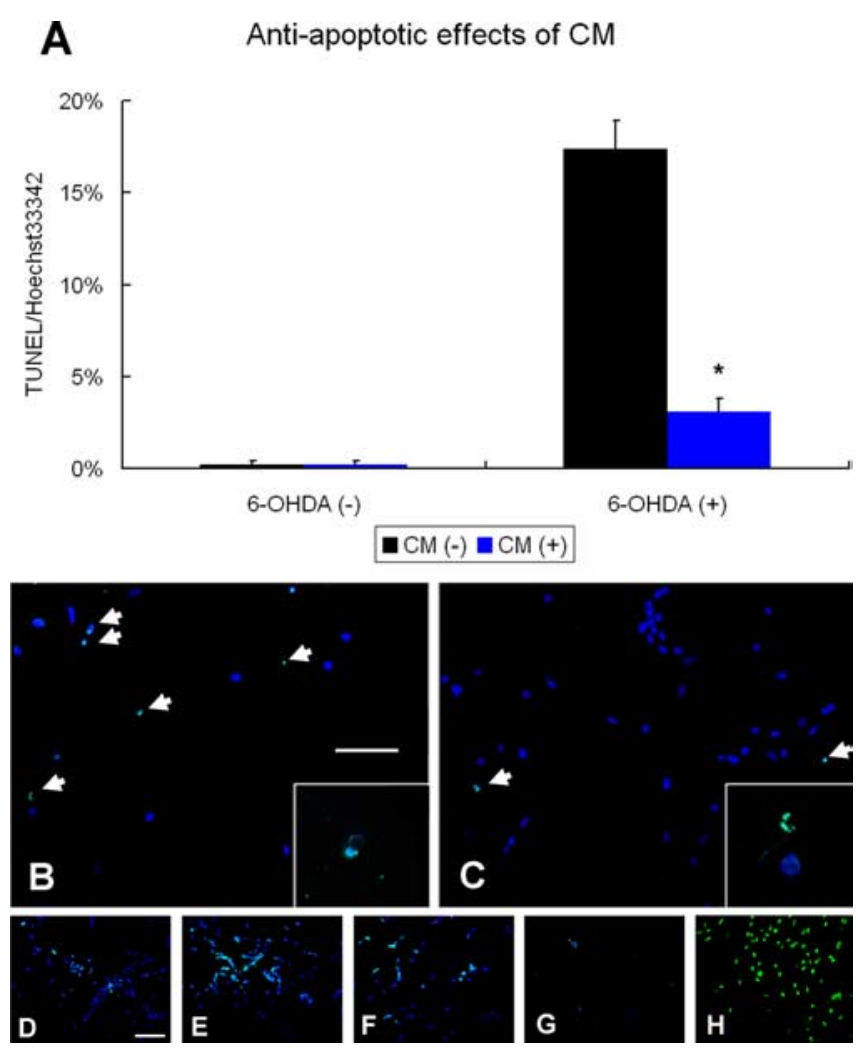

Figure 7. Anti-apoptotic effects of HB1.F3 cell-derived CM and c-kit and TrkB expression in 6-OHDA-exposed SH-SY5Y cells. A, Administration of the CM significantly reduced the ratio of TUNEL-positive apoptotic cells to Hoechst33342-positive viable cells after 6-0HDA exposure. Data are shown as percentages \pm SE of cell viability relative to the untreated control. ${ }^{*} p<0.01$ versus 6-0HDA-exposed untreated SH-SY5Y cells. CM, Culture media of HB1.F3 cells. B, C, TUNEL staining (green) and nuclear staining with Hoechst33342 (blue) revealed markedly decreased TUNEL-positive apoptotic (arrows) SH-SY5Y cells after 6-OHDA and CM treatment $(\boldsymbol{C}$ ) compared with 6-OHDA exposure without $C M$ treatment $(\boldsymbol{B})$. Insets are representative higher magnifications of TUNEL-positive cells in each panel. Scale bar: $60 \mu \mathrm{m}$; insets, $10 \mu \mathrm{m}$. D-G, c-kit expression (green) and nuclear staining with Hoechst33342 (blue) demonstrated that $1 \mu \mathrm{m}$ 6-OHDA exposure for $24 \mathrm{~h}$ upregulated c-kit expression. D, Untreated SH-SY5Y cells. E-G, 6-OHDA treatment at 1, 10, and $40 \mu \mathrm{m}$ to SH-SY5Y cells. Scale bar, $60 \mu \mathrm{m}$. $\boldsymbol{H}$, TrkB was strongly expressed on SH-SY5Y cells. Scale bar, $30 \mu \mathrm{m}$.

uted to the enhanced positive outcome. Such "neuroprotective" strategy is relevant to PD because motor symptoms do not occur until $70-80 \%$ of striatal nerve terminals and $50-60 \%$ of SNc perikarya have been depleted (Bernheimer et al., 1973; Riederer and Wuketich, 1976; Bezard et al., 2001).

\section{HB1.F3 cell grafts survive in the lesioned striatum}

Totipotential stem cells from bone marrow decrease their proliferative potencies with differentiation (Wagers, 2005). Even with daily immunosuppression, graft survival of v-myc oncogeneprimed HB1.F3 cells was $\sim 1 \%$ at 1 month after transplantation, which is relatively low compared with at least $5 \%$ graft survival with other neural stem/progenitor cells (Borlongan et al., 1998; Yang et al., 2004; Harrower et al., 2006). In addition, almost all transplanted cells resided at the original implantation site. Despite low graft survival and limited or absence of HB1.F3 cell migration, beneficial effects were observed, suggesting that secretory function of the cells, rather than the graft per se, mediated the observed neuroprotection. Nonetheless, the small number of surviving HB1.F3 cells may be clinically significant, especially if they were $\mathrm{TH}$ positive, because it was suggested that only 300 




B

$\mathrm{Bcl}-2$ protein assay

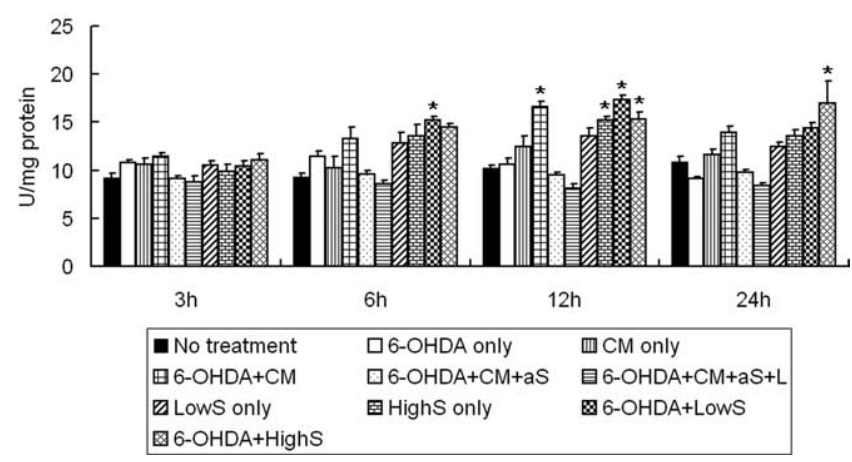

Figure 8. Neuroprotective effects of $\mathrm{CM}$ and SCF involves the PI3k/Akt pathway and $\mathrm{BCl}-2$ upregulation. $\boldsymbol{A}$, LY294002, a PI3k/Akt inhibitor, significantly reduced the neuroprotective effects induced by CM or SCF treatment. CM, Culture media of HB1.F3 cells; L, LY294002; aS, anti-SCF antibody; LowS, $500 \mathrm{pg} / \mathrm{ml} \mathrm{SCF}$. Data are shown as percentages \pm SE of cell viability relative to the untreated control. ${ }^{*} p<0.05$ versus $6-0 \mathrm{HDA}$-exposed untreated SH-SY5Y cells. ${ }^{\dagger} p<0.05$ versus $6-0 \mathrm{HDA}$-exposed SH-SY5Y cells with the CM or low dose of SCF treatment. $\boldsymbol{B}$, Cultured SH-SY5Y cells exposed to 6-OHDA and treated with CM or SCF displayed significantly higher $\mathrm{BCl}-2$ expression at $12 \mathrm{~h}$ after 6-0HDA exposure compared with untreated 6-0HDAexposed cell cultures. However, 6-0HDA alone produced a transient elevation of $\mathrm{BCl}-2$ expression in untreated $\mathrm{SH}-\mathrm{SY} 5 \mathrm{Y}$ cells at $6 \mathrm{~h}$ after the neurotoxin administration. In addition, $\mathrm{BCl}-2$ upregulation in 6-OHDA-exposed cells induced by CM treatment was cancelled by anti-SCF antibody and/or PI3k/Akt inhibitor. Data are shown as units per milligram of protein $\pm \mathrm{SE}$. CM, Culture media of HB1.F3 cells; aS, anti-SCF antibody; L, LY294002; LowS, 500 pg/mI SCF; HighS, $5 \mathrm{ng} / \mathrm{ml} \mathrm{SCF} .{ }^{*} p<0.05$ versus untreated SH-SY5Y cells. ${ }^{\dagger} p<0.05$ versus $6-0$ HDA-exposed SH-SY5Y cells with the CM.

grafted dopaminergic neurons are required to produce functional effects in PD (Brundin et al., 1988).

\section{Neuronal differentiation and synapse formation of HB1.F3 cell grafts}

Commitment to a neuronal lineage primarily determines the appropriateness of stem cells as donor source for transplant therapy in neurological disorders, including PD. Specific growth factors (Schuldiner et al., 2000), drug-inducible systems (Hoglinger et al., 2004), or viral vectors for gene expression and knockdown (Szulc et al., 2006) have been used to control cell proliferation and neuronal differentiation. Interestingly, the default system of stem cells, at least the ES cells, and the pathological status of host microenvironment appear to dictate neuronal commitment. Indeed, naive mouse ES cells differentiate into TH-positive neurons, along with expression of other mature neuronal markers, in the dopamine-depleted striatum (Bjorklund et al., 2002). However, human ES cell-derived dopaminergic neurons, which strongly expressed MAP2 and TH in vitro, were almost negative for $\mathrm{TH}$ and other mature neuronal markers in vivo (Park et al., 2005), suggesting the difficulty in controlling the stable expression of TH. In our study, some xenografted HB1.F3 cells in the lesioned striatum expressed MAP2 but not $\mathrm{TH}$, indicating that neuronal maturation without dopaminergic differentiation was achieved in this human-derived cell line. Notwithstanding this lack of dopaminergic differentiation, we observed neuroprotective effects of HB1.F3 cells, implying that mechanisms other than these cells becoming fully dopaminergic neurons mediated the therapeutic outcome.

To date, there exist limited studies examining synapse formation after transplantation of NSCs in PD models. Immunohistochemical analyses, using the nerve terminal differentiation marker synaptophysin, and electron microscopy studies have documented graft-host integration, as well as endogenous stem cells forming functional synapses with the nigrostriatal dopaminergic pathway (Sortwell et al., 1998; Zhao et al., 2003; Harrower et al., 2006), indicating a restoration of neuronal circuitry in PD. In the present study, there is partial evidence to suggest that preservation of this neuronal circuitry is achieved by the grafted HB1.F3 cells in that we show an intricate and dense pattern of synaptophysin immunoreactivity within the grafts. A longer maturation may reveal reciprocal innervation between the grafts and the host.

\section{HB1.F3 cell grafts afford nigrostriatal dopaminergic sparing against 6-OHDA}

Neuroprotective effects of stem cells have been equated with sparing of host nigrostriatal dopaminergic pathway in lesioned rodents (Akerud et al., 2001; Ericson et al., 2005). Astrocytes or NSCs engineered to secrete GDNF when transplanted into the nigra and striatum, respectively, before 6-OHDA lesion prevented dopaminergic depletion in the SNc to $80 \%$ (Akerud et al., 2001; Ericson et al., 2005). Preservation of the nigral TH neurons in our study was $60 \%$, indicating that transplantation before lesion is more beneficial than the same-day lesion-transplant paradigm. Interestingly, preservation of striatal TH fibers was produced only by intrastriatal transplantation of GDNF-secreting NSCs (Akerud et al., 2001) but not intranigral GDNF-secreting astrocytes (Ericson et al., 2005). The present intrastriatal HB1.F3 cell grafts spared both TH striatal fibers and nigral neurons from 6-OHDA neurotoxicity, but it appears that the acute postlesion timing of transplantation of HB1.F3 cells is critical for such therapeutic effects because grafting after a long delay after lesion does not lead to functional improvement (Kim et al., 2006). Additional studies are warranted to reveal optimal timing of transplantation after onset of parkinsonian symptoms, as well as to find the most conducive transplant site for maximal neuroprotection.

\section{HB1.F3 cell grafts enhance endogenous neurogenesis}

Neurogenesis in PD remains controversial. Dopamine depletion in PD rodent models and patients is thought to impair the proliferation and generation of neural precursor cells in the SVZ (Baker et al., 2004; Hoglinger et al., 2004). Equally compelling evidence, however, demonstrates that treatment with growth factors activates endogenous neurogenesis in the SVZ of PD model rats (Cooper and Isacson, 2004; Mohapel et al., 2005). Although significant migration was found in the transforming growth factor $\alpha(\mathrm{TGF} \alpha)$-generated progenitor cells, they remained multipotential (i.e., nestin but not $\mathrm{TH}$ positive) and did not improve rotational behavior (Cooper and Isacson, 2004). In our study, enhanced neurogenesis was detected in the SVZ of behaviorally recovered lesioned rats with intrastriatally grafted HB1.F3 cells. 
We found a slightly higher 140\% increase in BrdU-positive cells at 4 weeks after HB1.F3 cell transplantation compared with a $128 \%$ increase in SVZ cells expressing nestin after 4 weeks of TGF $\alpha$ administration (Cooper and Isacson, 2004). A closer look, however, at the proliferation induced by TGF $\alpha$ reveals that this growth factor appears as a robust promigratory factor in that the newly generated cells formed cell migratory waves in the adjacent striatum and septum (Cooper and Isacson, 2004). Although the migratory marker Dcx double labeled with BrdUpositive host cells in the SVZ of our HB1.F3 cell grafted animals, the lack of migration of these cells outside the SVZ suggests that the secreted factors from HB1.F3 cells might not have contained a high level of the migratory trigger TGF $\alpha$. Alternatively, the absence of prominent migration coupled with expression of neuronal markers in our neurogeneic cells implies that the secreted factors, such as SCF, are primarily involved in neuronal differentiation rather than migration.

\section{Neuronal differentiation of HB1.F3 cells in vitro}

A major criterion for establishing cell lines with neuronal differentiation potential, but with unlimited stemness, requires that the stem cell pool is not depleted despite cells adopting a neuronal lineage (Wagers, 2005). The present cultured HB1.F3 cells were nestin, $\mathrm{HuD}$ (postmitotic neuronal marker), $\beta$-tubulin IIIpositive, some MAP2-positive, and rarely NeuN (matured neuronal marker) positive and $\mathrm{HuC}$ (very early neuronal marker) negative, indicating that these cells are pluripotent embryoniclike stem cells expressing neural genes (Marusich et al., 1994; Goolsby et al., 2003; Gerrard et al., 2005). Based on their very immature neuronal phenotypic features in vitro, the observed neuronal differentiation of grafted HB1.F3 cells within 1 month after transplantation, despite the absence of TH expression, indicates a robust neuronal commitment of this stem cell line. Notwithstanding such neuronal differentiation in vivo, the majority of cultured HB1.F3 cells expressing a "stemness" identity prompted us to evaluate whether naive, undifferentiated HB1.F3 cells could exert neuroprotective effects via a non-neuronal differentiation mechanism involving trophic factor secretion. Of note, a recent study showed that systemically transplanted neurosphere-derived multipotent precursors promote neuroprotection in a mouse model of chronic CNS inflammation by maintaining their undifferentiated phenotypic features (Pluchino et al., 2005).

\section{Neuroprotective effects of HB1.F3 cell-secreted SCF}

The c-kit receptor-ligand (i.e., SCF) complex is involved in embryonic development of neural tube (Keshet et al., 1991), postnatal cerebellar development (Manova et al., 1992), and adult hippocampal-dependent learning (Motro et al., 1996). Localized expression of c-kit in the brain, including the neocortex, hippocampus, cerebellum, and striatum, of rodents (Zhang and Feimmunoprecipitation.
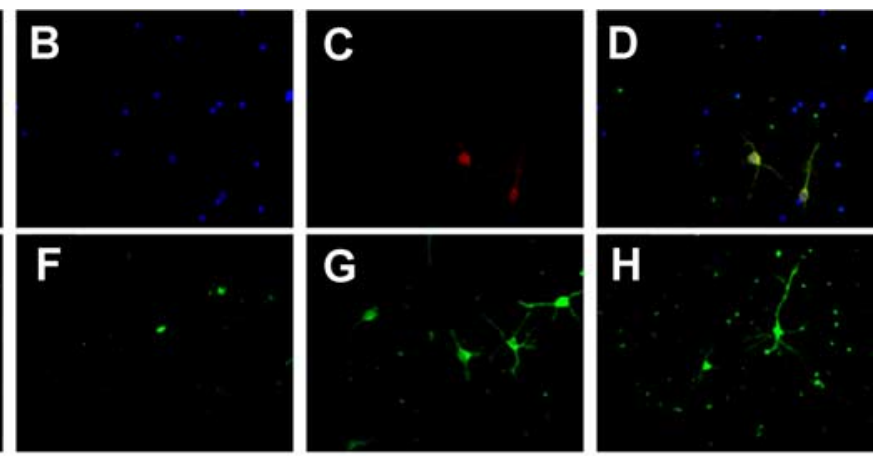

MTT assay

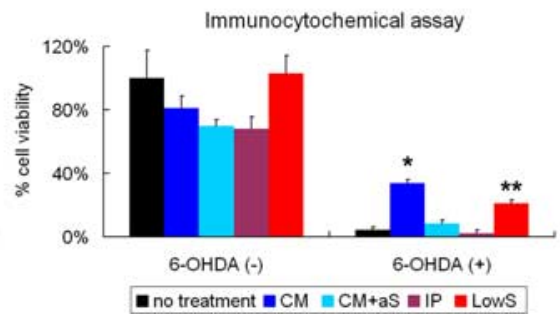

- no treatment $=\mathrm{CM}=\mathrm{CM}+\mathrm{aS}=\mathrm{IP}=$ LowS

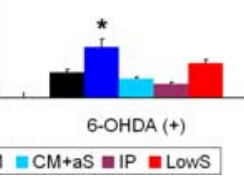

Figure 9. Neuroprotective effects of $\mathrm{CM}$ and SCF on 6-OHDA-exposed fetal rat-derived dopaminergic neurons. $\boldsymbol{A}-\boldsymbol{D}$, Fetal
rat-derived dopaminergic neurons expressed TH $(\boldsymbol{A})$ and c-kit $(\boldsymbol{C})$ ( $\boldsymbol{B}$, Hoechst33342; $\boldsymbol{D}$, merged image). Scale bar, $30 \mu \mathrm{m}$. $\boldsymbol{E}-\boldsymbol{H}, \mathrm{TH}$ 作 versus 6-OHDA-exposed dopaminergic neurons without treatment, with CM plus anti-SCF antibody, and SCF-removed CM by

doroff, 1997), suggests that stimulation of the c-kit by its ligand SCF could exert physiological effects in the CNS. Here, we report prominent c-kit expression in the SH-SY5Y cells and high levels of SCF in the CM of HB1.F3 cells, indicating that such receptorligand interaction exists in our in vitro model, which could be a target for neuroprotection. Indeed, SCF treatment has been demonstrated to trigger neurogenesis in c-kit-expressing neuronal cultures and neuroproliferative zones of the adult brain (Jin et al., 2002). Moreover, recombinant SCF induces migration in vitro and in vivo through the activation of c-kit on neural stem/progenitor cells (Sun et al., 2004). These studies support our concept that neuroprotection produced by CM from HB1.F3 cells is primarily via SCF secretion of HB1.F3 cells, which targeted the c-kit receptors expressed by SH-SY5Y cells. The blockade of neuroprotective effects of CM and SCF by anti-SCF antibody provides additional evidence of a receptor-ligand-mediated neuroprotection. The expression of c-kit in vivo, specifically in the proliferative SVZ (Jin et al., 2002) adjacent to the transplanted lesioned striatum, likely facilitated the HB1.F3 cell-secreted SCF and the subsequent neuroprotection. An equally novel finding in our study is the observation that the in vitro therapeutic benefits of HB1.F3-derived CM and SCF were accompanied by Bcl-2 upregulation, which were blocked by application of PI3k/Akt inhibitor. These results indicate abrogation of apoptotic cell death as the likely downstream mechanism underlying HB1.F3 neuroprotective effects. Because apoptosis has been increasingly implicated as a significant neurodegenerative event in PD (Junn et al., 2005; Petit et al., 2005), treatment strategies, such as the trans- 
plantation of HB1.F3 cells, designed to prevent dopaminergic neurons from succumbing to the apoptotic cell death should be considered in PD. The possibility to deliver cells from the periphery, especially in view of the putative c-kit-SCF migratory capacity of HB1.F3 cells, would allow a minimally invasive and less traumatic transplantation surgery for early-stage PD patients.

\section{References}

Akerud P, Canals JM, Snyder EY, Arenas E (2001) Neuroprotection through delivery of glial cell line-derived neurotrophic factor by neural stem cells in a mouse model of Parkinson's disease. J Neurosci 21:8108-8118.

Alexi T, Borlongan CV, Faull RL, Williams CE, Clark RG, Gluckman PD, Hughes PE (2000) Neuroprotective strategies for basal ganglia degeneration: Parkinson's and Huntington's diseases. Prog Neurobiol 60:409-470.

Arenas E (2002) Stem cells in the treatment of Parkinson's disease. Brain Res Bull 57:795-808.

Armstrong RJ, Hurelbrink CB, Tyers P, Ratcliffe EL, Richards A, Dunnett SB, Rosser AE, Barker RA (2002) The potential for circuit reconstruction by expanded neural precursor cells explored through porcine xenografts in a rat model of Parkinson's disease. Exp Neurol 175:98-111.

Ashman LK (1999) The biology of stem cell factor and its receptor C-kit. Int J Biochem Cell Biol 31:1037-1051.

Baker SA, Baker KA, Hagg T (2004) Dopaminergic nigrostriatal projections regulate neural precursor proliferation in the adult mouse subventricular zone. Eur J Neurosci 20:575-579.

Baldauf K, Reymann KG (2005) Influence of EGF/bFGF treatment on proliferation, early neurogenesis and infarct volume after transient focal ischemia. Brain Res 1056:158-167.

Ben-Hur T, Idelson M, Khaner H, Pera M, Reinhartz E, Itzik A, Reubinoff BE (2004) Transplantation of human embryonic stem cell-derived neural progenitors improves behavioral deficit in Parkinsonian rats. Stem Cells 22:1246-1255.

Bernheimer H, Birkmayer W, Hornykiewicz O, Jellinger K, Seitelberger F (1973) Brain dopamine and the syndromes of Parkinson and Huntington. Clinical, morphological and neurochemical correlations. J Neurol Sci 20:415-455.

Bezard E, Dovero S, Prunier C, Ravenscroft P, Chalon S, Guilloteau D, Crossman AR, Bioulac B, Brotchie JM, Gross CE (2001) Relationship between the appearance of symptoms and the level of nigrostriatal degeneration in a progressive 1-methyl-4-phenyl-1,2,3,6-tetrahydropyridine-lesioned macaque model of Parkinson's disease. J Neurosci 21:6853-6861.

Bjorklund LM, Sanchez-Pernaute R, Chung S, Andersson T, Chen IY, McNaught KS, Brownell AL, Jenkins BG, Wahlestedt C, Kim KS, Isacson O (2002) Embryonic stem cells develop into functional dopaminergic neurons after transplantation in a Parkinson rat model. Proc Natl Acad Sci USA 99:2344-2349.

Borlongan CV (2000) Transplantation therapy for Parkinson's disease. Expert Opin Investig Drugs 9:2319-2330.

Borlongan CV, Sanberg PR (2002) Neural transplantation for treatment of Parkinson's disease. Drug Discov Today 7:674-682.

Brundin P, Barbin G, Strecker RE, Isacson O, Prochiantz A, Bjorklund A (1988) Survival and function of dissociated rat dopamine neurones grafted at different developmental stages or after being cultured in vitro. Brain Res 467:233-243.

Borlongan CV, Saporta S, Poulos SG, Othberg A, Sanberg PR (1998) Viability and survival of hNT neurons determine degree of functional recovery in grafted ischemic rats. NeuroReport 9:2837-2842.

Borlongan CV, Sanberg PR, Freeman TB (1999) Neural transplantation for neurodegenerative disorders. Lancet 353 [Suppl 1]:SI29-SI30.

Calne DB (1984) Progress in Parkinson's disease. N Engl J Med 310:523-524.

Chen J, Li Y, Zhang R, Katakowski M, Gautam SC, Xu Y, Lu M, Zhang Z, Chopp M (2004) Combination therapy of stroke in rats with a nitric oxide donor and human bone marrow stromal cells enhances angiogenesis and neurogenesis. Brain Res 1005:21-28.

Chen S, Xianwen C, Dehua X, Zhenguo L, Lingfei X, Smith SW, Zhongcheng Z (2003) Behavioral correction of Parkinsonian rats following the transplantation of immortalized fibroblasts genetically modified with $\mathrm{TH}$ and GCH genes. Parkinsonism Relat Disord 9 [Suppl 2]:S91-S97.
Cho T, Bae JH, Choi HB, Kim SS, McLarnon JG, Suh-Kim H, Kim SU, Min CK (2002) Human neural stem cells: electrophysiological properties of voltage-gated ion channels. NeuroReport 13:1447-1452.

Cohen PS, Chan JP, Lipkunskaya M, Biedler JL, Seeger RC (1994) Expression of stem cell factor and c-kit in human neuroblastoma. The Children's Cancer Group. Blood 84:3465-3472.

Cooper O, Isacson O (2004) Intrastriatal transforming growth factor alpha delivery to a model of Parkinson's disease induces proliferation and migration of endogenous adult neural progenitor cells without differentiation into dopaminergic neurons. J Neurosci 24:8924-8931.

Dowd E, Dunnett SB (2004) Deficits in a lateralized associative learning task in dopamine-depleted rats with functional recovery by dopamine-rich transplants. Eur J Neurosci 20:1953-1959.

Ericson C, Georgievska B, Lundberg C (2005) Ex vivo gene delivery of GDNF using primary astrocytes transduced with a lentiviral vector provides neuroprotection in a rat model of Parkinson's disease. Eur J Neurosci 22:2755-2764.

Farlie PG, Dringen R, Rees SM, Kannourakis G, Bernard O (1995) bcl-2 transgene expression can protect neurons against developmental and induced cell death. Proc Natl Acad Sci USA 92:4397-4401.

Flax JD, Aurora S, Yang C, Simonin C, Wills AM, Billinghurst LL, Jendoubi M, Sidman RL, Wolfe JH, Kim SU, Snyder EY (1998) Engraftable human neural stem cells respond to developmental cues, replace neurons, and express foreign genes. Nat Biotechnol 16:1033-1039.

Freed CR (2002) Will embryonic stem cells be a useful source of dopamine neurons for transplant into patients with Parkinson's disease? Proc Natl Acad Sci USA 99:1755-1757.

Freed CR, Greene PE, Breeze RE, Tsai WY, DuMouchel W, Kao R, Dillon S, Winfield H, Culver S, Trojanowski JQ, Eidelberg D, Fahn S (2001) Transplantation of embryonic dopamine neurons for severe Parkinson's disease. N Engl J Med 344:710-719.

Freeman TB, Olanow CW, Hauser RA, Nauert GM, Smith DA, Borlongan CV, Sanberg PR, Holt DA, Kordower JH, Vingerhoets FJ, Snow BJ, Caine D, Gauger LL (1995) Bilateral fetal nigral transplantation into the postcommissural putamen in Parkinson's disease. Ann Neurol 38:379-388.

Gerrard L, Rodgers L, Cui W (2005) Differentiation of human embryonic stem cells to neural lineages in adherent culture by blocking bone morphogenetic protein signaling. Stem Cells 23:1234-1241.

Goldman S (2005) Stem and progenitor cell-based therapy of the human central nervous system. Nat Biotechnol 23:862-871.

Goolsby J, Marty MC, Heletz D, Chiappelli J, Tashko G, Yarnell D, Fishman PS, Dhib-Jalbut S, Bever Jr CT, Pessac B, Trisler D (2003) Hematopoietic progenitors express neural genes. Proc Natl Acad Sci USA 100:14926-14931.

Greisen MH, Altar CA, Bolwig TG, Whitehead R, Wortwein G (2005) Increased adult hippocampal brain-derived neurotrophic factor and normal levels of neurogenesis in maternal separation rats. J Neurosci Res 79:772-778.

Harrower TP, Tyers P, Hooks Y, Barker RA (2006) Long-term survival and integration of porcine expanded neural precursor cell grafts in a rat model of Parkinson's disease. Exp Neurol 197:56-69.

Hoglinger GU, Rizk P, Muriel MP, Duyckaerts C, Oertel WH, Caille I, Hirsch EC (2004) Dopamine depletion impairs precursor cell proliferation in Parkinson disease. Nat Neurosci 7:726-735.

Hornykiewicz O (1973) Parkinson's disease: from brain homogenate to treatment. Fed Proc 32:183-190.

Iancu R, Mohapel P, Brundin P, Paul G (2005) Behavioral characterization of a unilateral 6-OHDA-lesion model of Parkinson's disease in mice. Behav Brain Res 162:1-10.

Jin K, Mao XO, Sun Y, Xie L, Greenberg DA (2002) Stem cell factor stimulates neurogenesis in vitro and in vivo. J Clin Invest 110:311-319.

Jung CG, Hida H, Nakahira K, Ikenaka K, Kim HJ, Nishino H (2004) Pleiotrophin mRNA is highly expressed in neural stem (progenitor) cells of mouse ventral mesencephalon and the product promotes production of dopaminergic neurons from embryonic stem cell-derived nestinpositive cells. FASEB J 18:1237-1239.

Junn E, Taniguchi H, Jeong BS, Zhao X, Ichijo H, Mouradian MM (2005) Interaction of DJ-1 with Daxx inhibits apoptosis signal-regulating kinase 1 activity and cell death. Proc Natl Acad Sci USA 102:9691-9696.

Kang UJ, Fisher LJ, Joh TH, O’Malley KL, Gage FH (1993) Regulation of dopamine production by genetically modified primary fibroblasts. J Neurosci 13:5203-5211. 
Keshet E, Lyman SD, Williams DE, Anderson DM, Jenkins NA, Copeland NG, Parada LF (1991) Embryonic RNA expression patterns of the c-kit receptor and its cognate ligand suggest multiple functional roles in mouse development. EMBO J 10:2425-2435.

Kim SU (2004) Human neural stem cells genetically modified for brain repair in neurological disorders. Neuropathology 24:159-171.

Kim SU, Park IH, Kim TH, Kim KS, Choi HB, Hong SH, Bang JH, Lee MA, Joo IS, Lee CS, Kim YS (2006) Brain transplantation of human neural stem cells transduced with tyrosine hydroxylase and GTP cyclohydrolase 1 provides functional improvement in animal models of Parkinson disease. Neuropathology 26:129-140.

Kirik D, Rosenblad C, Bjorklund A, Mandel RJ (2000) Long-term rAAVmediated gene transfer of GDNF in the rat Parkinson's model: intrastriatal but not intranigral transduction promotes functional regeneration in the lesioned nigrostriatal system. J Neurosci 20:4686-4700.

Klages N, Zufferey R, Trono D (2000) A stable system for the high-titer production of multiply attenuated lentiviral vectors. Mol Ther 2:170-176.

Kordower JH, Freeman TB, Snow BJ, Vingerhoets FJ, Mufson EJ, Sanberg PR, Hauser RA, Smith DA, Nauert GM, Perl DP, Olanow CW (1995) Neuropathological evidence of graft survival and striatal reinnervation after the transplantation of fetal mesencephalic tissue in a patient with Parkinson's disease. N Engl J Med 332:1118-1124.

Kuroiwa T, Lee EG, Danning CL, Illei GG, McInnes IB, Boumpas DT (1999) CD40 ligand-activated human monocytes amplify glomerular inflammatory responses through soluble and cell-to-cell contact-dependent mechanisms. J Immunol 163:2168-2175.

Lang AE, Lozano AM (1998a) Parkinson's disease. First of two parts. N Engl J Med 339:1044-1053.

Lang AE, Lozano AM (1998b) Parkinson's disease. Second of two parts. N Engl J Med 339:1130-1143.

Langston JW (2005) The promise of stem cells in Parkinson disease. J Clin Invest 115:23-25.

Leff SE, Rendahl KG, Spratt SK, Kang UJ, Mandel RJ (1998) In vivo L-DOPA production by genetically modified primary rat fibroblast or 9L gliosarcoma cell grafts via coexpression of GTPcyclohydrolase I with tyrosine hydroxylase. Exp Neurol 151:249-264.

Lindvall O, Bjorklund A (2004) Cell therapy in Parkinson's disease. NeuroRx 1:382-393.

Lindvall O, Rehncrona S, Gustavii B, Brundin P, Astedt B, Widner H, Lindholm T, Bjorklund A, Leenders KL, Rothwell JC, Frackowiak R, Marsden CD, Johnels B, Steg G, Freedman R, Hoffer BJ, Seiger A, Strömberg I, Bygdeman M, Olson L (1988) Fetal dopamine-rich mesencephalic grafts in Parkinson's disease. Lancet 2:1483-1484.

Lindvall O, Widner H, Rehncrona S, Brundin P, Odin P, Gustavii B, Frackowiak R, Leenders KL, Sawle G, Rothwell JC, Bjöurklund A, Marsden CD (1992) Transplantation of fetal dopamine neurons in Parkinson's disease: one-year clinical and neurophysiological observations in two patients with putaminal implants. Ann Neurol 31:155-165.

Linnekin D (1999) Early signaling pathways activated by c-Kit in hematopoietic cells. Int J Biochem Cell Biol 31:1053-1074.

Llado J, Haenggeli C, Maragakis NJ, Snyder EY, Rothstein JD (2004) Neural stem cells protect against glutamate-induced excitotoxicity and promote survival of injured motor neurons through the secretion of neurotrophic factors. Mol Cell Neurosci 27:322-331.

Lu P, Jones LL, Snyder EY, Tuszynski MH (2003) Neural stem cells constitutively secrete neurotrophic factors and promote extensive host axonal growth after spinal cord injury. Exp Neurol 181:115-129.

Lundberg C, Englund U, Trono D, Bjorklund A, Wictorin K (2002) Differentiation of the RN33B cell line into forebrain projection neurons after transplantation into the neonatal rat brain. Exp Neurol 175:370-387.

Madrazo I, Leon V, Torres C, Aguilera MC, Varela G, Alvarez F, Fraga A, Drucker-Colin R, Ostrosky F, Skurovich M, Franco R (1988) Transplantation of fetal substantia nigra and adrenal medulla to the caudate nucleus in two patients with Parkinson's disease. N Engl J Med 318:51.

Manova K, Bachvarova RF, Huang EJ, Sanchez S, Pronovost SM, Velazquez E, McGuire B, Besmer P (1992) c-kit receptor and ligand expression in postnatal development of the mouse cerebellum suggests a function for c-kit in inhibitory interneurons. J Neurosci 12:4663-4676.

Marusich MF, Furneaux HM, Henion PD, Weston JA (1994) Hu neuronal proteins are expressed in proliferating neurogenic cells. J Neurobiol 25:143-155.
Maruyama W, Youdim MB, Naoi M (2001) Antiapoptotic properties of rasagiline, $N$-propargylamine- $1(R)$-aminoindan, and its optical $(S)$ isomer, TV1022. Ann NY Acad Sci 939:320-329.

Maruyama W, Akao Y, Carrillo MC, Kitani K, Youdium MB, Naoi M (2002) Neuroprotection by propargylamines in Parkinson's disease: suppression of apoptosis and induction of prosurvival genes. Neurotoxicol Teratol 24:675-682.

McGill GG, Horstmann M, Widlund HR, Du J, Motyckova G, Nishimura EK, Lin YL, Ramaswamy S, Avery W, Ding HF, Jordan SA, Jackson IJ, Korsmeyer SJ, Golub TR, Fisher DE (2002) Bcl2 regulation by the melanocyte master regulator Mitf modulates lineage survival and melanoma cell viability. Cell 109:707-718.

Mendez I, Sanchez-Pernaute R, Cooper O, Vinuela A, Ferrari D, Bjorklund L, Dagher A, Isacson O (2005) Cell type analysis of functional fetal dopamine cell suspension transplants in the striatum and substantia nigra of patients with Parkinson's disease. Brain 128:1498-1510.

Modo M, Stroemer RP, Tang E, Patel S, Hodges H (2003) Effects of implantation site of dead stem cells in rats with stroke damage. NeuroReport 14:39-42.

Mohapel P, Frielingsdorf H, Haggblad J, Zachrisson O, Brundin P (2005) Platelet-derived growth factor (PDGF-BB) and brain-derived neurotrophic factor (BDNF) induce striatal neurogenesis in adult rats with 6-hydroxydopamine lesions. Neuroscience 132:767-776.

Motro B, Wojtowicz JM, Bernstein A, van der Kooy D (1996) Steel mutant mice are deficient in hippocampal learning but not long-term potentiation. Proc Natl Acad Sci USA 93:1808-1813.

Olanow CW, Goetz CG, Kordower JH, Stoessl AJ, Sossi V, Brin MF, Shannon KM, Nauert GM, Perl DP, Godbold J, Freeman TB (2003) A doubleblind controlled trial of bilateral fetal nigral transplantation in Parkinson's disease. Ann Neurol 54:403-414.

Olsnes C, Heimdal JH, Kross K, Olofsson J, Aarstad HJ (2002) Mechanisms for monocyte activation in co-culture with autologous tumor spheroids. Cell Immunol 219:11-21.

Park CH, Minn YK, Lee JY, Choi DH, Chang MY, Shim JW, Ko JY, Koh HC, Kang MJ, Kang JS, Rhie DJ, Lee YS, Son H, Moon SY, Kim KS, Lee SH (2005) In vitro and in vivo analyses of human embryonic stem cellderived dopamine neurons. J Neurochem 92:1265-1276.

Paxinos GW, Watson C (1998) The rat brain in stereotaxic coordinates. San Diego: Academic.

Petit A, Kawarai T, Paitel E, Sanjo N, Maj M, Scheid M, Chen F, Gu Y, Hasegawa H, Salehi-Rad S, Wang L, Rogaeva E, Fraser P, Robinson B, St. George-Hyslop P, Tandon A (2005) Wild-type PINK1 prevents basal and induced neuronal apoptosis, a protective effect abrogated by Parkinson disease-related mutations. J Biol Chem 280:34025-34032.

Pluchino S, Zanotti L, Rossi B, Brambilla E, Ottoboni L, Salani G, Martinello M, Cattalini A, Bergami A, Furlan R, Comi G, Constantin G, Martino G (2005) Neurosphere-derived multipotent precursors promote neuroprotection by an immunomodulatory mechanism. Nature 436:266-271.

Rafuse VF, Soundararajan P, Leopold C, Robertson HA (2005) Neuroprotective properties of cultured neural progenitor cells are associated with the production of sonic hedgehog. Neuroscience 131:899-916.

Richardson RM, Broaddus WC, Holloway KL, Fillmore HL (2005) Grafts of adult subependymal zone neuronal progenitor cells rescue hemiparkinsonian behavioral decline. Brain Res 1032:11-22.

Riederer P, Wuketich S (1976) Time course of nigrostriatal degeneration in parkinson's disease. A detailed study of influential factors in human brain amine analysis. J Neural Transm 38:277-301.

Schallert T, Fleming SM, Leasure JL, Tillerson JL, Bland ST (2000) CNS plasticity and assessment of forelimb sensorimotor outcome in unilateral rat models of stroke, cortical ablation, parkinsonism and spinal cord injury. Neuropharmacology 39:777-787.

Schuldiner M, Yanuka O, Itskovitz-Eldor J, Melton DA, Benvenisty N (2000) Effects of eight growth factors on the differentiation of cells derived from human embryonic stem cells. Proc Natl Acad Sci USA 97:11307-11312.

Sieber-Blum M (1998) Growth factor synergism and antagonism in early neural crest development. Biochem Cell Biol 76:1039-1050.

Snyder BJ, Olanow CW (2005) Stem cell treatment for Parkinson's disease: an update for 2005. Curr Opin Neurol 18:376-385.

Sonntag KC, Simantov R, Isacson O (2005) Stem cells may reshape the prospect of Parkinson's disease therapy. Brain Res Mol Brain Res 134:34-51.

Sortwell CE, Blanchard BC, Collier TJ, Elsworth JD, Taylor JR, Roth RH, Redmond Jr DE, Sladek Jr JR (1998) Pattern of synaptophysin immu- 
noreactivity within mesencephalic grafts following transplantation in a parkinsonian primate model. Brain Res 791:117-124.

Spina MB, Squinto SP, Miller J, Lindsay RM, Hyman C (1992) Brainderived neurotrophic factor protects dopamine neurons against 6-hydroxydopamine and $N$-methyl-4-phenylpyridinium ion toxicity: involvement of the glutathione system. J Neurochem 59:99-106.

Sun L, Lee J, Fine HA (2004) Neuronally expressed stem cell factor induces neural stem cell migration to areas of brain injury. J Clin Invest 113:1364-1374.

Sun ZH, Lai YL, Zeng WW, Zhao D, Ye ZW, Zuo HC, Xie ZP (2003) Mesencephalic progenitors can improve rotational behavior and reconstruct nigrostriatal pathway in PD rats. Acta Neurochir Suppl 87:175-180.

Svendsen CN, Caldwell MA, Shen J, ter Borg MG, Rosser AE, Tyers P, Karmiol S, Dunnett SB (1997) Long-term survival of human central nervous system progenitor cells transplanted into a rat model of Parkinson's disease. Exp Neurol 148:135-146.

Szulc J, Wiznerowicz M, Sauvain MO, Trono D, Aebischer P (2006) A versatile tool for conditional gene expression and knockdown. Nat Methods 3:109-116.

Takagi Y, Takahashi J, Saiki H, Morizane A, Hayashi T, Kishi Y, Fukuda H, Okamoto Y, Koyanagi M, Ideguchi M, Hayashi H, Imazato T, Kawasaki H, Suemori H, Omachi S, Iida H, Itoh N, Nakatsuji N, Sasai Y, Hashimoto N (2005) Dopaminergic neurons generated from monkey embryonic stem cells function in a Parkinson primate model. J Clin Invest 115:102-109.

Wagers AJ (2005) Stem cell grand SLAM. Cell 121:967-970.
Wang JY, Wu JN, Cherng TL, Hoffer BJ, Chen HH, Borlongan CV, Wang Y (2001) Vitamin D(3) attenuates 6-hydroxydopamine-induced neurotoxicity in rats. Brain Res 904:67-75.

Yang M, Donaldson AE, Marshall CE, Shen J, Iacovitti L (2004) Studies on the differentiation of dopaminergic traits in human neural progenitor cells in vitro and in vivo. Cell Transplant 13:535-547.

Yasuhara T, Shingo T, Kobayashi K, Takeuchi A, Yano A, Muraoka K, Matsui T, Miyoshi Y, Hamada H, Date I (2004) Neuroprotective effects of vascular endothelial growth factor (VEGF) upon dopaminergic neurons in a rat model of Parkinson's disease. Eur J Neurosci 19:1494-1504.

Yasuhara T, Shingo T, Muraoka K, Kobayashi K, Takeuchi A, Yano A, Wenji Y, Kameda M, Matsui T, Miyoshi Y, Date I (2005) Early transplantation of an encapsulated glial cell line-derived neurotrophic factor-producing cell demonstrating strong neuroprotective effects in a rat model of Parkinson disease. J Neurosurg 102:80-89.

Yoshizaki T, Inaji M, Kouike H, Shimazaki T, Sawamoto K, Ando K, Date I, Kobayashi K, Suhara T, Uchiyama Y, Okano H (2004) Isolation and transplantation of dopaminergic neurons generated from mouse embryonic stem cells. Neurosci Lett 363:33-37.

Zhang SC, Fedoroff S (1997) Cellular localization of stem cell factor and c-kit receptor in the mouse nervous system. J Neurosci Res 47:1-15.

Zhao M, Momma S, Delfani K, Carlen M, Cassidy RM, Johansson CB, Brismar H, Shupliakov O, Frisen J, Janson AM (2003) Evidence for neurogenesis in the adult mammalian substantia nigra. Proc Natl Acad Sci USA 100:7925-7930. 